\title{
Wildfires vs. Sustainable Forest Partitioning
}

\author{
G.-Fivos Sargentis ${ }^{1, * \mathbb{C}}$, Romanos Ioannidis ${ }^{1}$, Ioannis Bairaktaris ${ }^{1}$, Evangelia Frangedaki ${ }^{2} \mathbb{D}$, \\ Panayiotis Dimitriadis ${ }^{1}\left(\mathbb{D}\right.$, Theano Iliopoulou ${ }^{1}{ }^{\mathbb{D}}$, Demetris Koutsoyiannis ${ }^{1}\left(\mathbb{B}\right.$ and Nikos D. Lagaros ${ }^{3}$
}

1 Laboratory of Hydrology and Water Resources Development, School of Civil Engineering, National Technical University of Athens, 15772 Athens, Greece; romanos.ioannidis@gmail.com (R.I.); april18g@hotmail.com (I.B.); pandim@itia.ntua.gr (P.D.); tiliopoulou@hydro.ntua.gr (T.I.); dk@itia.ntua.gr (D.K.)

2 Department III, Architectural Language, Communication and Design, School of Architecture, National Technical University of Athens, 15780 Athens, Greece; efraggedaki@arch.ntua.gr

3 Institute of Structural Analysis and Antiseismic Research, School of Civil Engineering, National Technical University of Athens, 15780 Athens, Greece; nlagaros@central.ntua.gr

* Correspondence: fivos@itia.ntua.gr

Citation: Sargentis, G.-F.; Ioannidis, R.; Bairaktaris, I.; Frangedaki, E.; Dimitriadis, P.; Iliopoulou, T.; Koutsoyiannis, D.; Lagaros, N.D. Wildfires vs. Sustainable Forest Partitioning. Conservation 2022, 2 , 195-218. https://doi.org/10.3390/ conservation 2010013

Academic Editor: Antoni Margalida

Received: 19 January 2022

Accepted: 5 March 2022

Published: 8 March 2022

Publisher's Note: MDPI stays neutral with regard to jurisdictional claims in published maps and institutional affiliations.

Copyright: (C) 2022 by the authors. Licensee MDPI, Basel, Switzerland. This article is an open access article distributed under the terms and conditions of the Creative Commons Attribution (CC BY) license (https:// creativecommons.org/licenses/by/ $4.0 /)$.

\begin{abstract}
There is a widespread perception that every year wildfires are intensifying on a global scale, something that is often used as an indicator of the adverse impacts of global warming. However, from the analysis of wildfires that have occurred in the US, Canada, and Mediterranean countries, a trend that justifies this perception could not be identified. Arguably, instead of blaming climate change, research on the mitigation of wildfires should be re-directed to forest management policy and practices. Forests are admirable and complex natural ecosystems, and fires, albeit devastating, can be attributed to both human activity and to natural processes that contribute to their rebirth, with the latter constituting an intrinsic and perpetual process of the forest ecosystem. Other than their important ecological value, forests are, in the 21st century, also a capital resource, for many people's livelihoods depend on them. In this study, we proposed a method for taking mitigation measures against wildfires based on the partitioning of forests, considering both the protection of the ecosystem and the inhabitants and aiming to utilize their co-dependent nature for the general protection and preservation of forests. As a case study, we analyzed the current devastating fire in Euboea (occurred in August 2021), initially in terms of the spatio-temporal progression of the actual wildfire that lasted several days and then by examining how an implementation of the proposed method in the study area could contribute to both the recovery of the ecosystem and the enhancement of the quality of life of the inhabitants as well as their long-term protection.
\end{abstract}

Keywords: fire; wildfires; megafires; forest; land use; sustainability; fire prevention

\section{Introduction}

Fire is not an unexpected phenomenon that can be solely attributed to human activity [1] but a process that also occurs naturally since, in many cases, it is considered a necessary mechanism for the rebirth of forests [2]. Therefore, we have to expect fires. Several large wildfires have occurred worldwide in recent years and have been given international publicity. These fires are often used as an indicator of climate change [3]. However, are fires worse than before? Are we defenseless against future natural hazards that are beyond mitigation, or is there room for improvement in forest management policy and practice?

Wildfires affect ecosystems and inhabitants. A common perception is that in recent years, fires and their impact have increased. However, Section 2 presents data analyzed by the broken line smoothing (BLS) model [4], which do not confirm this perception in general. Therefore, forest fires are a phenomenon with which we have to co-exist, and thus we must explore ways to face it. 
Section 3 describes the phenomenon of fire and different ways of dealing with it. We can distinguish them as mitigation (firefighters, fire planes) and prevention measures. As we observe a systematic weakness of the mitigation methods to control the fire, we focus on related studies which propose a different approach based on precaution (prevention), with measures focusing on land uses [5-7] and alternative forest management.

Section 4 describes the effects of fire, looking not only at the obvious (e.g., the destruction of the natural environment) but also at the impact of the phenomenon on the prosperity and cohesion of local communities.

Section 5 describes clustering as a growth process giving relative examples. In turn, it describes how partitioning (de-clustering) can be seen as a protection process showing examples of its quantification and its application to forest areas.

Section 6 examines the case study of the fire that occurred in the period of 3-11 August 2021 in Euboea, Greece. The general characteristics of the fire are explored, its evolution in time and space is illustrated, and the characteristics of the event are quantified. In the same section, the effects of the fire, including the negative impacts for occupation in local communities, and the zone that stopped the fire are described. This section also highlights a historical example of a land-use change that eventually created the zone that stopped the recent fire and illustrates how forest partitioning could be helpful to control fires.

Section 7 approaches a formula for a recovery method. As a general feature, it is demonstrated that local communities have suffered terrible damage by losing their wealth which was dependent on the burnt areas. They are characteristically referred to as "immigrants" within their own property and land. In order to overcome this issue, a redistribution of the land is proposed which could be a field of new wealth-generating activity for the inhabitants, while it could also be a new measure of protection through forest partitioning. At the same time, people require fast new infrastructures and development; therefore innovative technological solutions (such as $3 \mathrm{D}$ printing) that could be implemented to construct the required infrastructures for development in a short time are discussed.

The conclusions of Section 8 argue that the proposed method of forest partitioning is feasible and, with appropriate policy interventions (redistribution of the land), it can provide a solution to forest protection as well as to the cohesion of local communities on the basis of the principle of "endogenous productive reconstruction" [8-10]. However, further research is needed on the specifications of the design of the new land uses.

\section{Inspecting Time Series of Fires}

In August 2021, an alarming UN report blamed human activity for "unprecedented" changes to the climate [11]. Fires have been used as an indicator of climate change, with different studies arguing that fires have the trend to be more destructive every year [12-15]. Data from National Interagency Fire Center USA [16] (1983-2021) also confirm this trend (Figure 1). However, the reconstruction of time series between 1926 and 1970 using available data from the library of USA Genus Bureau [17] allowed us to see that the positive trend was not verified. On the contrary, in other countries, such as Canada, a decreasing trend is observed between 1920 and 1960 and between 1980 and 2020, while an increasing trend of burnt areas is observed between 1960 and 1980 (data adopted from [18,19]) (Figure 2). In addition, another interesting observation is that the trend of the number of fires and the trend of burnt areas are not always of the same direction or magnitude.

Other time series, adopted from European Mediterranean countries (Portugal, Spain, France, Italy, Greece) [20] (Figure 3), showcase that burnt areas from wildfires decreased during the 1980-2016 period and that the number of fires shows a high fluctuation with no obvious trend and with only an increasing trend from 1995 to 2005. 


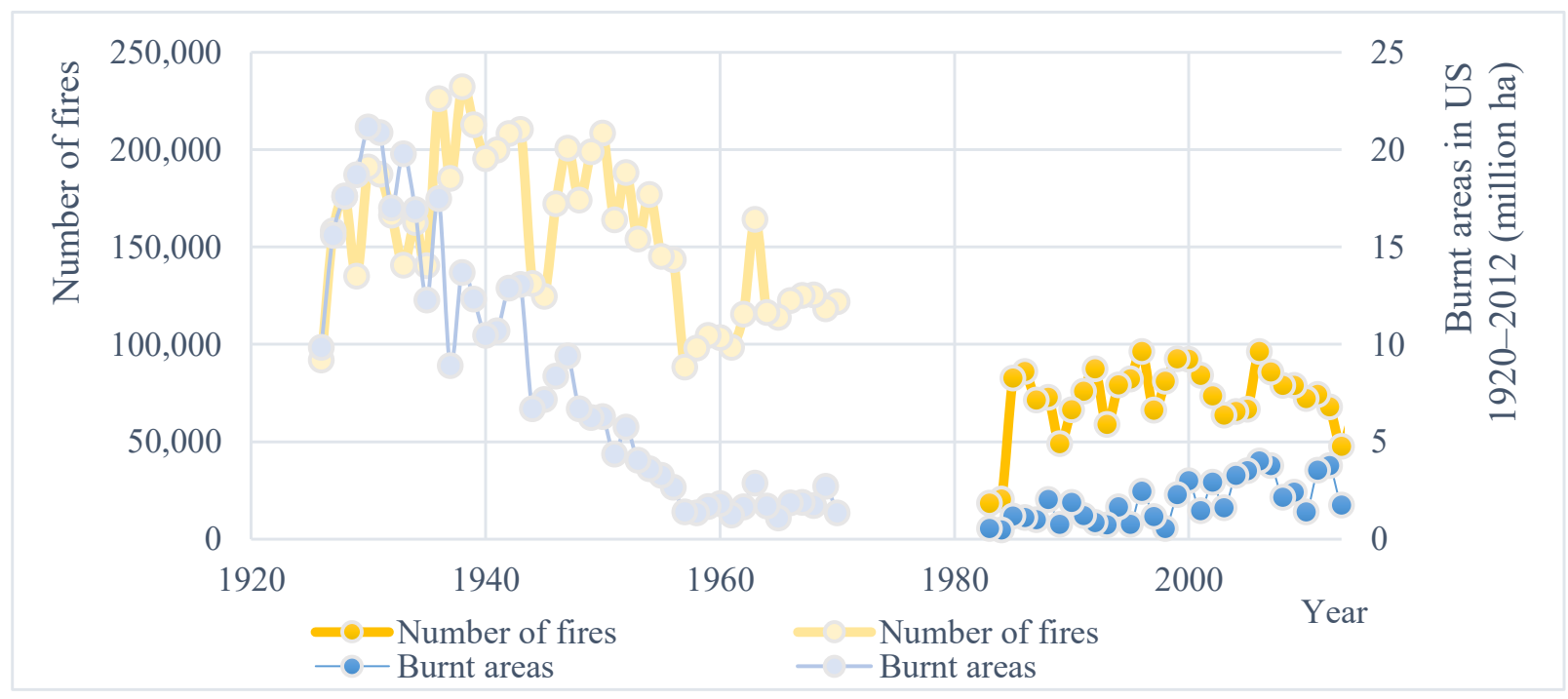

Figure 1. The evolution of wildfires in USA (1926-1970 and 1983-2021). Data before 1980 are impacted by larger uncertainty (lack of satellite vision) and are depicted in gray.

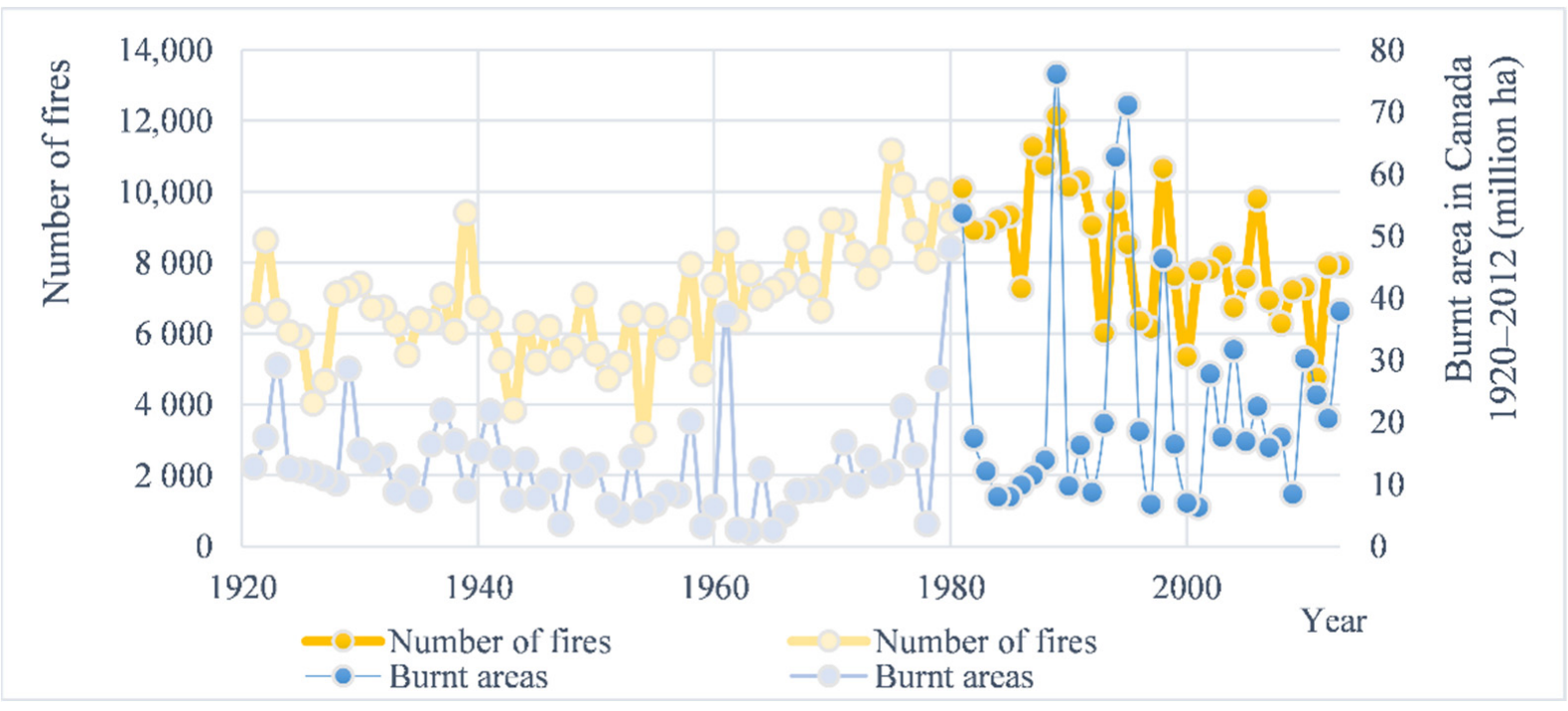

Figure 2. The evolution of wildfires in Canada (1920-2013). Data before 1980 are impacted by larger uncertainty (lack of satellite vision) and are depicted in gray.

In order to study the burnt areas in Greece, we collected data from the Hellenic Fire Service (HFS) (2000-2021) [21], Hellenic Forest Service, European Forest Fire Information System (EFFIS) (2000-2019) [22], and a related European Union report [20], which showed small differences. The data concerning the numbers of fires were collected from the Hellenic Fire Service and showed deviations from the rest of European countries in the order of magnitude of 10,000 ha (e.g., $2013=10,196 ; 2014=6834 ; 2015=6729 ; 2016=10,259$; $2017=10,356 ; 2018=8006 ; 2019=9500 ; 2020=11,799)$, which was possibly due to including even small events that were not considered otherwise significant (Figure 4). Note that data before 1980, depicted in gray, exhibit large variability and uncertainty (probably due to lack of satellite vision) [23]. 


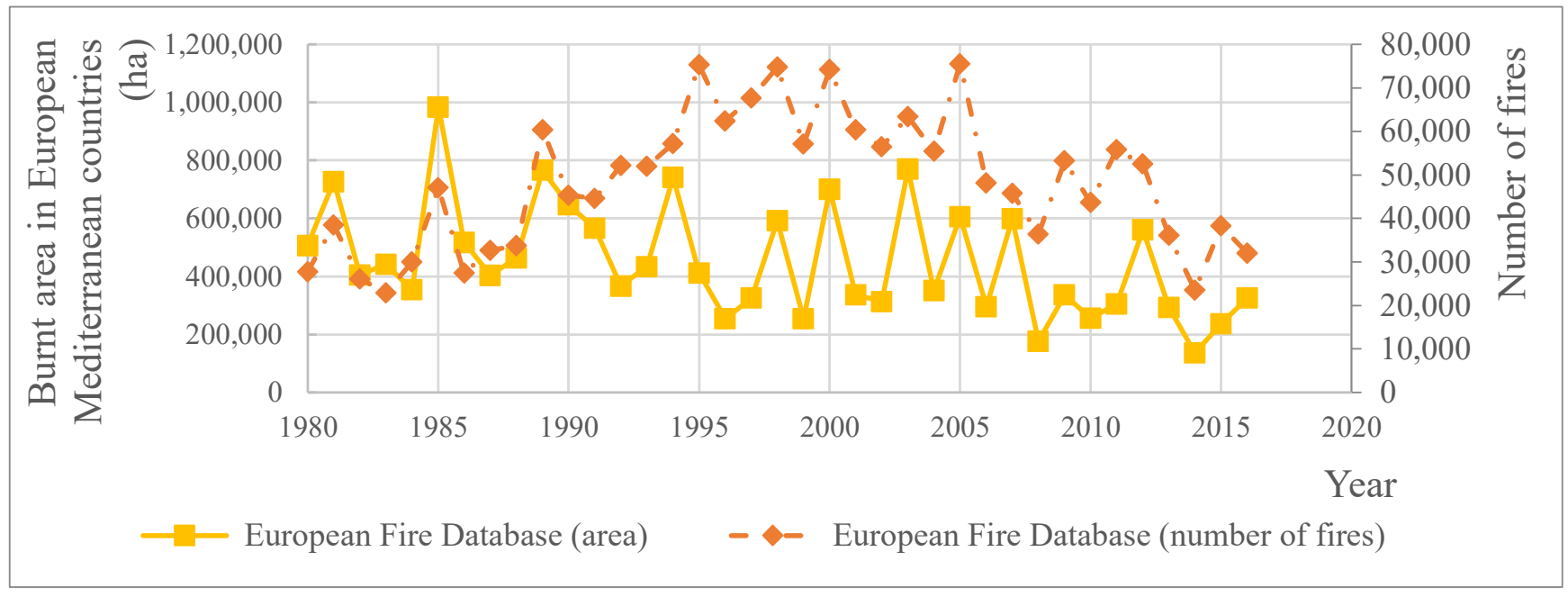

Figure 3. The evolution of wildfires in European Mediterranean countries (1980-2016).

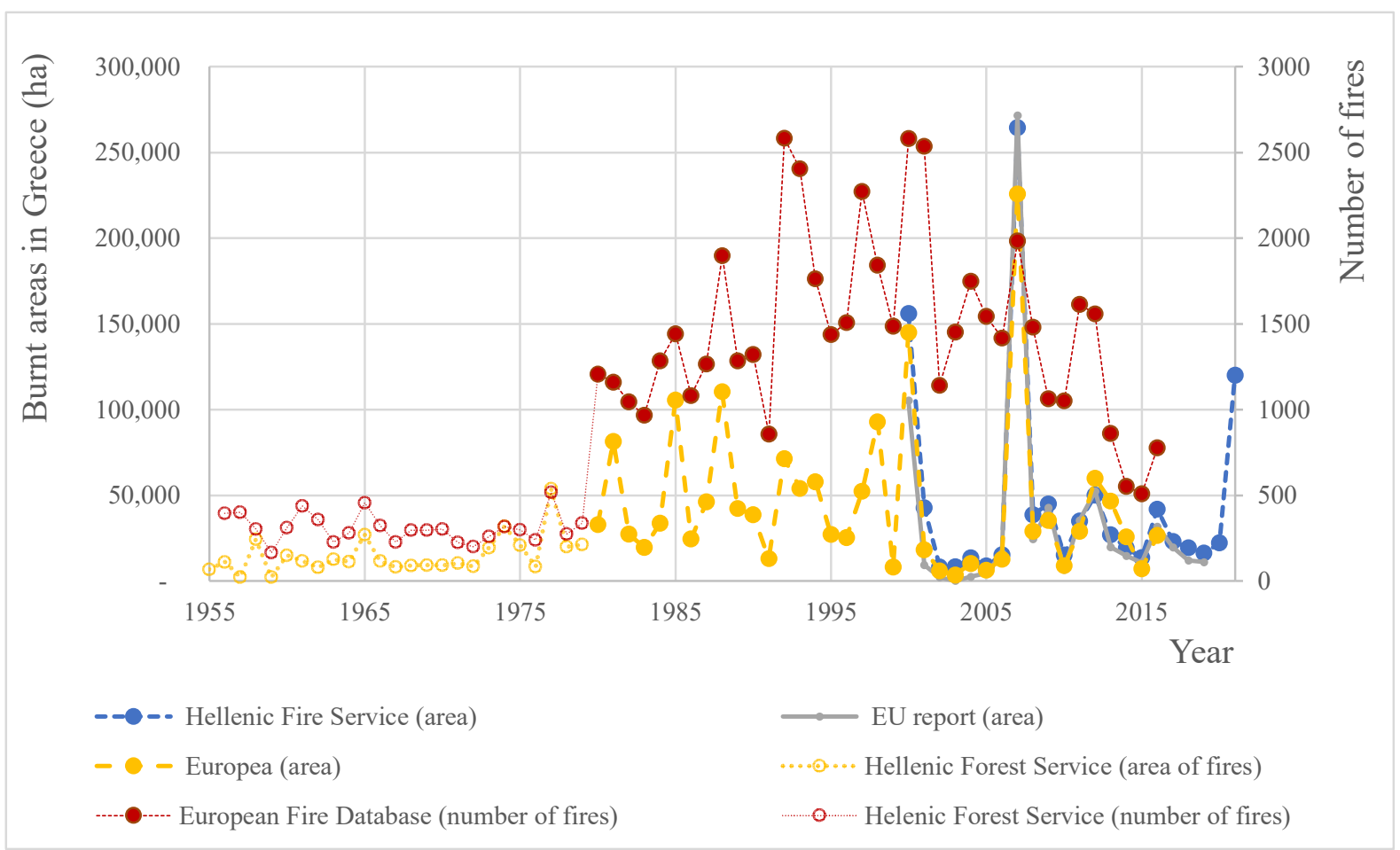

Figure 4. The evolution of wildfires in Greece (1980-2021). Data before 1980 are impacted by larger uncertainty (lack of satellite vision) and are depicted in gray.

Inspecting the impact of each fire incident, we attempted to check if more megafires occur today than in the past decades. A way to examine this is to plot the annual-scale ratio of burnt areas per number of fires (Figure 5).

Analyzing the data, we note that there is not a standard mathematical expression of the dependence of $y$ on $x$ (e.g., linear, logarithmic, power, polynomial) which could simplify the problem of curve fitting. Therefore, the determination of the parameters of a mathematical expression, a task typically accomplished using regression (or least-squares) techniques, cannot be done.

Traditionally, these cases have been remedied by graphical techniques such as drawing an "eyeball" curve on a scatterplot of points $\left(x_{i}, y_{i}\right)$. This is apparently a non-parametric approach in the sense that it does not use any parameters of a specified law (in contrast to 
parametric regression techniques) but has the flaws of being subjective and unsusceptible to an algorithmic treatment, and thus it is not programmable to computers.

Another alternative is the use of smoothing techniques in which the fitted value of $y$ for any value of $x$ is determined from the available data points $\left(x_{i}, y_{i}\right)$ using weights for each one so that the weight for $\left(x_{i}, y_{i}\right)$ is large if $x$ is close to $x_{i}$ and small otherwise [24,25].

We chose to analyze the data using the broken line smoothing model (BLS) $[4,26]$ which is considered as a better alternative to numerical smoothing and interpolating methods yet close to the approach of the traditional graphical method [27]. The method is also closely related to piecewise linear regression and to smoothing splines, as it approximates a smooth curve that may be drawn for the data points $\left(x_{i}, y_{i}\right)$ with a broken line (or open polygon) which can be numerically estimated by means of a least-squares fitting procedure.

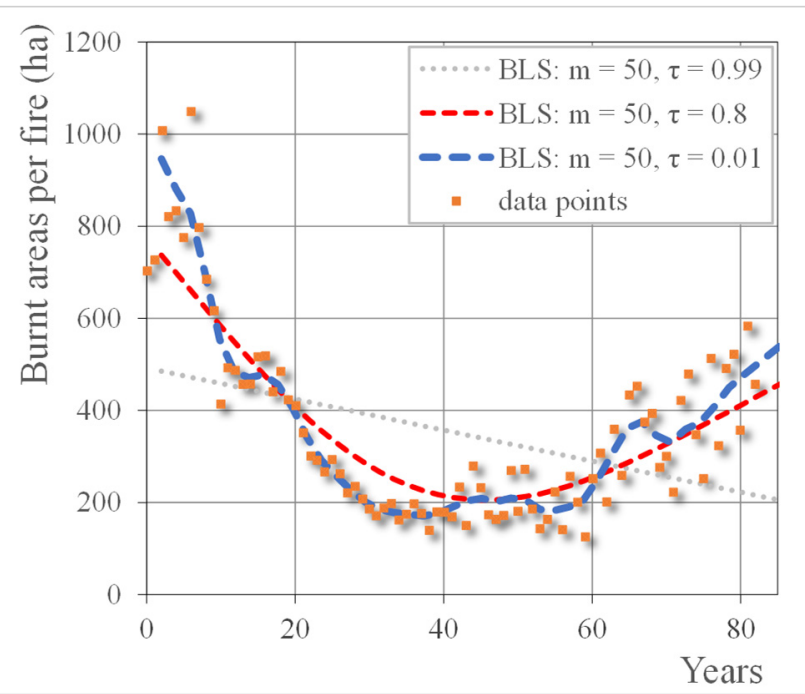

(a)

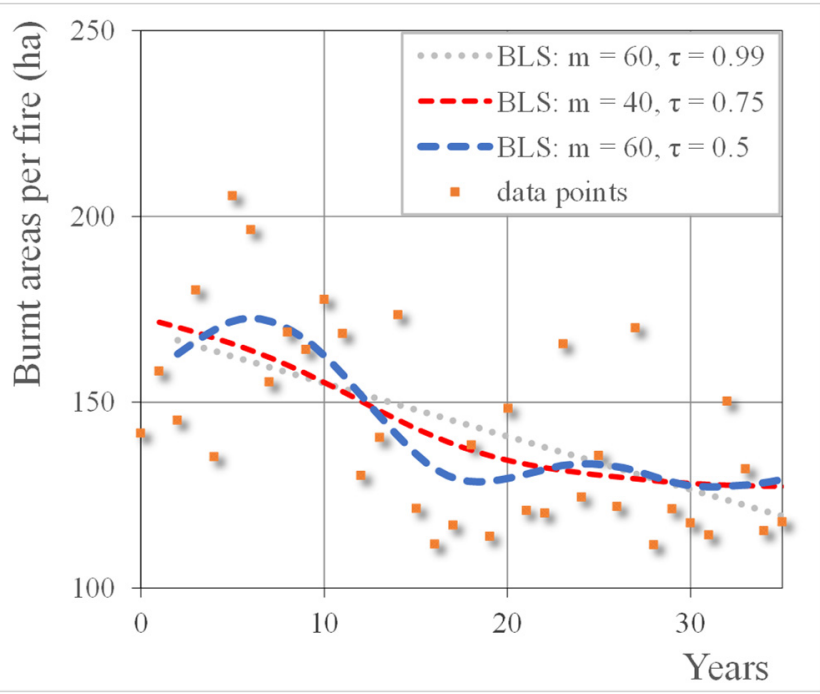

(c)

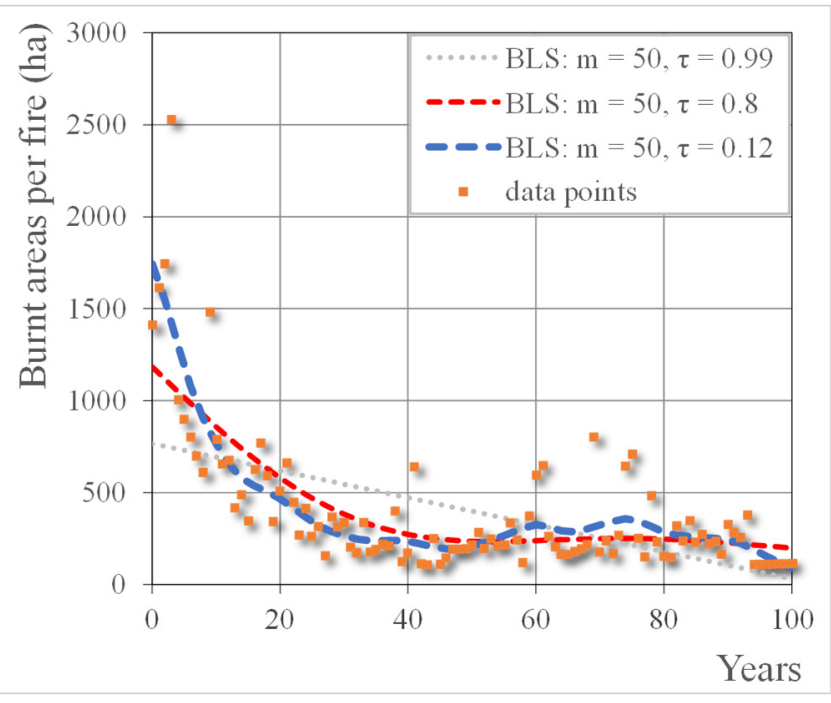

(b)

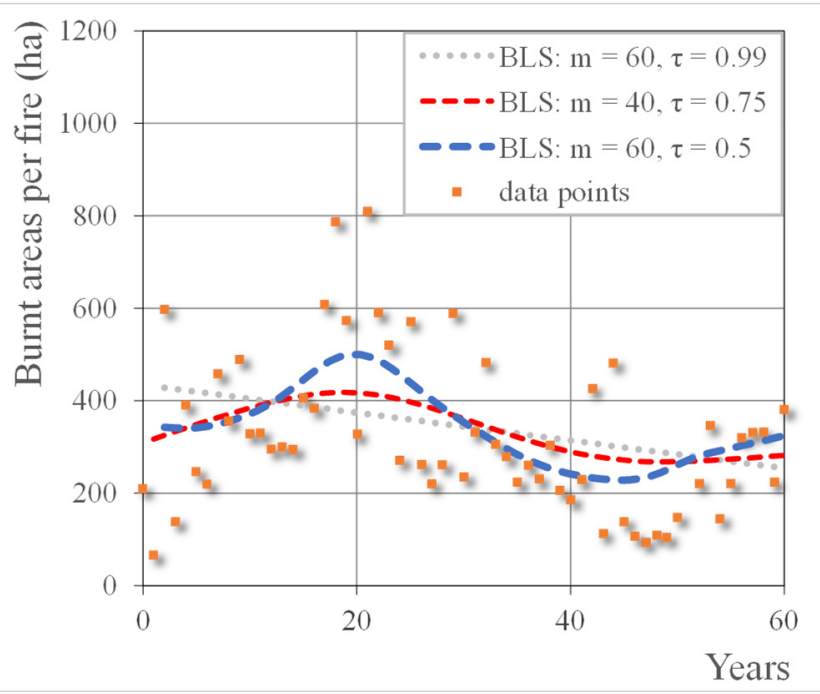

(d)

Figure 5. Burnt areas per number of fires (annual ratio). Dash lines show the trend of the phenomenon adopting alternative parameters of BLS. (a) US data: 1926-1970 and 1983-2021; (b) Canada data: 1920-2013; (c) Mediterranean countries data: 1980-2016; (d) Greece data: 1980-2016.

Although we observed an increasing trend in the US in the last 40 years (which was also observed by Nunes [28] in Portugal for the last 30 years), this trend cannot be detected 
either in Canada, the Mediterranean countries, or Greece. Therefore, a systematic trend is not obvious.

Fires are devastating [29,30]; however, according to the examined data, in recent years, their magnitude does not seem to be increasing, as referenced also in other related studies for other areas [31-33].

\section{The Event of the Fire}

\subsection{The Evolution of Fire}

Forests are a precious ecological source that hosts a significant part of our society, and the practice of fire mitigation should not be left undeveloped, nor should relevant shortcomings be attributed to uncontrollable natural phenomena.

Fire requires three elements to expand-oxygen, heat, and fuel—which are also known as "the triangle of fire". In wildfires, the oxygen depends on the wind conditions, the air temperature, and the fuel within the combustible materials [34,35].

However, wildfires are a more complex phenomenon. The evolution of wildfires also depends on the technological aspects of prediction, mitigation, the populations' density, and the "resident fire culture". In addition, crucial parameters of the evolution of the fire are: the relief of the landscape as rugged relief supports the fire [36,37], with high wind speeds that accelerate the flames spreading the fire [38,39].

There are two methods to face fire: reactive methods that face the front of the fire when the fire occurs and proactive (prevention) methods.

\subsection{Reactive Methods of Facing Fires}

The reactive ways are based on waiting for the phenomenon to occur in order to face it [40].

Despite the technological evolution [41-43], it seems that there is still an incredible weakness to mitigating fires with reactive ways [44].

Keeley noted [34]:

Firefighting aims to stop the running edge of the fire either by constructing a fire break

(a line where all burnable material has been removed) or by applying water or a foam mixture to reduce the surface tension of water droplets for easier penetration into the soil or biomass layer (the same principle as used in dish-washing detergent.

Fires are confined with firefighting planes, ground forces (equipped firefighters), and local volunteers. However, the effectiveness of these forces is often limited, and many times, the fire escapes, creating a forehead that cannot be easily managed.

\subsection{Proactive Methods of Facing Fires}

Since repressive methods for firefighting are not reliable, another method of firefighting is a defensive way that is based on prevention. One of the most common prevention tools is anti-fire zones, which are specifically designed based on deforestation and by planting suitable tree types that can delay fire expansion.

A typical anti-fire zone in Greece has about $20 \mathrm{~m}$ in width, but, in August 2021 in Euboia, we saw the fire easily passing the anti-fire zones (e.g., fires in Attica passed through national road with almost $50 \mathrm{~m}$ in width five times [45]). Gofas [46] described that an anti-fire zone is effective only when accompanied by specific actions (e.g., counterfire) from terrestrial forces. However, counterfire is not an acceptable practice in 2021 in Greece.

Other preventive ways such as changing land uses [47] or controlling burning using the partitioning of forests [48] have been proposed.

\section{The Results of Fire}

In modern "urban thinking", we consider that forests play an important role in society and the environment due to their high-value ecosystem and their high aesthetic value. However, this is only one of the various aspects of forests.

People who live in urban places are not always aware that forests are part of intense human activity and a precious source of income for the inhabitants of the nearby area, 
e.g., in Greece, for grazing goats and cattle, collecting resin of the trees, cutting trees for timber, and various other types of cultivations and livestock.

The society around forests is constructed in small (mainly autonomous) or bigger villages, with limited connection to the mainstream of infrastructures, central management, and central political scenery. Thus, fires can destruct valuable natural resources of an essential social system that completely depends on them.

\section{Clustering and Growth, Partitioning and Protection}

\subsection{Quantification of Clustering}

A method to estimate 2D clustering or absence of spatio-temporal dependence is through the climacogram (i.e., the variance of the averaged spatio-temporal process vs. spatio-temporal scale). The stochastic analysis in the scale domain (instead of the traditional lag or frequency domains) is shown to exhibit several advantages as a robust means to identify, model, and simulate dependence with a focus on the long-range dependence behavior or Hurst-Kolmogorov (HK) clustering behavior (also known as the Hurst phenomenon). The HK clustering is an attribute of a multidimensional (1D, 2D, etc.) stationary stochastic process with an arbitrary marginal distribution function and a fractal behavior on small scales of the dependence structure and a power type on large scales, yielding a high probability of low- or high-magnitude events to group together in space and time (see a review and several applications in Dimitriadis et al., 2021 [49]). The measure for the quantification of clustering is the climacogram integral; the larger the value of the climacogram integral, the higher clustering is.

Clustering as a growth process is described in Section $\mathrm{S} 1$ of the supplementary material and is depicted in Figures S1-S6 [50-57].

\subsection{Partitioning and Protection}

A more holistic inspection of natural evolution reveals, however, hidden elements of clustering. Dinosaurs were the biggest living creatures in nature, but about 66 million years ago, they disappeared. Smaller animals such as mammals survived because of "Being small. If you're small you probably have a large population and thus a wider genetic diversity" [58]. In this sense, even though clustering can be important for the economy and is associated with goals of growth, partitioning is a way of protection by reducing dependencies and risks associated with centralized infrastructure. Therefore, it is reasonable to examine how this method of decentralization and partitioning for the reduction of risks could be applied in forests and in particular in favor of their protection from wildfires.

Partitioning of forests is not a novel idea. For example, anti-fire zones share the same logic, but it can be argued that in practice, they have often been found to have limited effectiveness in the evolution of fire [59]. Several studies propose the facing of fires based on prevention measures focusing on land uses $[5,6,60-62]$ and alternative forest mitigation measures. Bajocco and Ricotta noted [63]:

For most land-cover classes, fire does not occur as expected from a random null model; rather, it behaves selectively, showing marked preference (or avoidance) in terms of fire number and fire size.

Moreira et al. noted [7]:

From a management perspective, land cover (related to vegetation structure and fuel loads) is the only landscape variable influencing fire behaviour that can be manipulated.

There are also other alternatives for land uses to control fire. Odum proposed "firecontrolled forests" [64] which:

... yields less wood than a tree farm does (that is, young trees, all of about the same age, planted in rows and harvested on a short rotation schedule), but it provides a greater protective cover for the landscape, wood of higher quality, and a home for game birds. 
Studying dynamics, causes, and policies of forest fires in Portugal, Mateus and Fernandes noted [65]:

Most of the unburnt surface has one or more of these features: urban, agricultural or agroforestry land use; relatively low population density; flat or undulated terrain; relatively low rainfall.

A problem with the cultural aspect of protection against wildfires is that the landscape often requires more than 10 years for its recovery/rebirth. Therefore, the danger for the forest will only re-emerge after a long period over which people will have overlooked the threat (learning from the previous fire). The cultural forgetfulness issue transcends just the regrowth of fuels and involves acceptable levels of change, the sporadic nature of wildfires, sensitivity to smoke, and other issues.

Mapping the evolution of fire in the case study of the fire in Euboea in August 2021, we investigate the role of the clustering of the forest in the evolution of fire and the role of partitioning as one of the fundamental mechanisms that could have stopped the disaster. In order to keep the memory active when forests will be again in danger (on average after 10-20 years), a new approach is proposed, based on the dependence of fires' evolution on the clustering of the forests.

According to that, the aim of the proposed methodology is to ensure the preservation of forest partitioning by the creation of sustainable clustered forest zones (SCFZs). SCFZs are linear or circled zones at least $500 \mathrm{~m}$ thick, aiming to support multi-purpose utilities, mainly focused around the energy-water-food nexus [66]. Considering the scale of a disaster such as that of the examined Euboea wildfire which will be described analytically as a case study in the next section, it is reasonable to consider the loss of a small part of the forest in order to safeguard a much larger area. The target of the SCFZs is the creation of Sustainable Islands (SaIs), which are defined as forest areas isolated by nonflammable land. SCFZs could act as protection against larger and more uneven disasters. An example of forest partitioning is given in Figure 6 for the north part of the forests of Euboea Island.

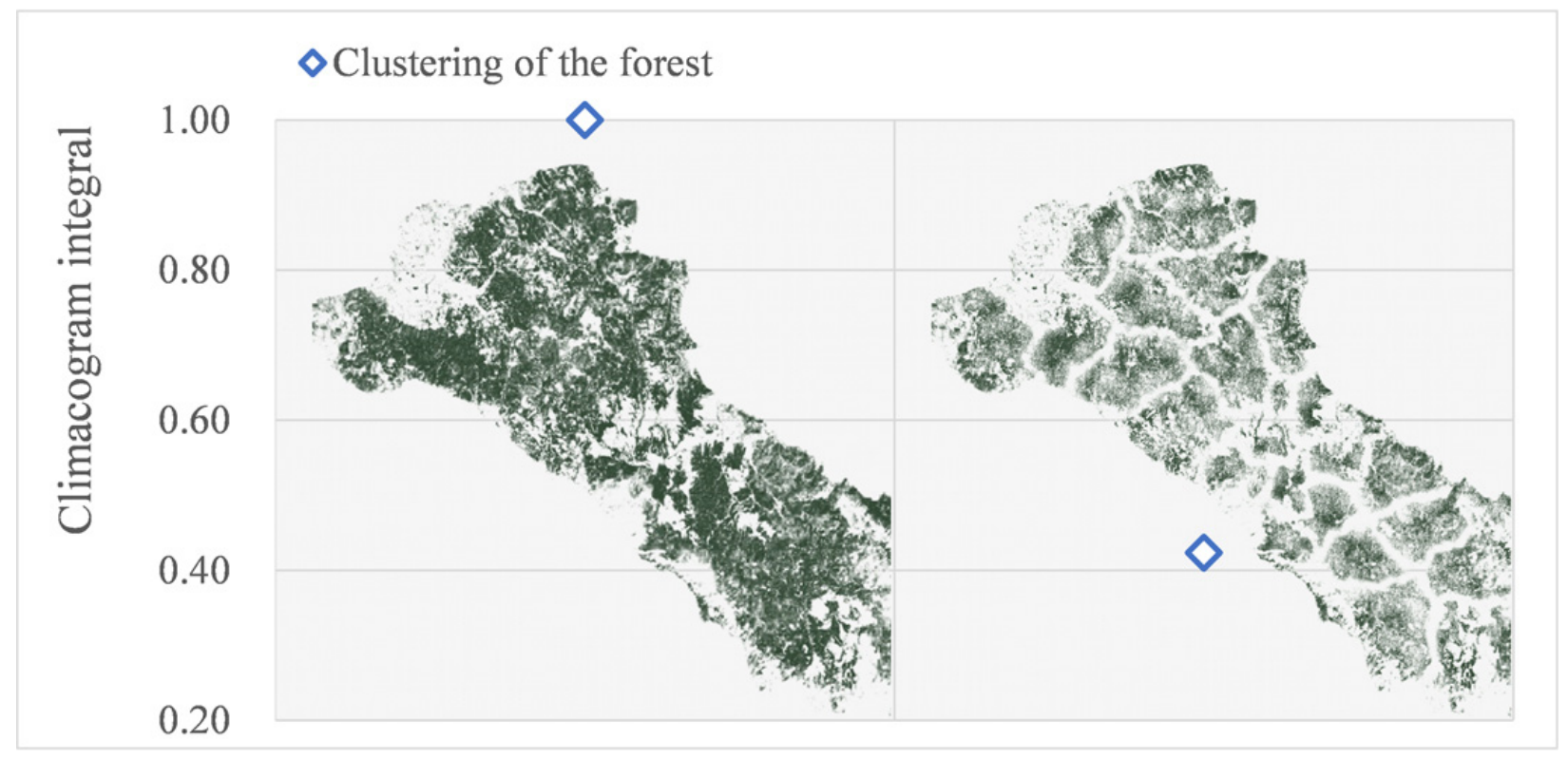

Figure 6. On the left, the clustering of the forests before the fire; on the right, a theoretical partitioning of the forest with SCFZs.

The difference of SCFZs from classic anti-fire zones is, other than their size, the fact that they are attributed with new land uses, which will promote the maintenance of these areas in synergy with local communities. It is possible that SCFZs could be perceived negatively by inhabitants and visitors as development works in forest areas are considered 
a threat to wildlife and to scientific fields of landscapes [67-69]. However, in the way modern societies are formed in order to protect valuable resources, all of these parameters have to be considered.

Greek philosopher Kastoriadis [70] noted that:

Humans develop ecological consciousness when they confront the waste they produce.

By analogy to the case of wildfires, the burnt areas can be considered as the "waste" from the uncontrollable evolution of fires, while the ecological consciousness is the realization of the need to protect forests, even if the required measures require funds or transformations of forest shape which might be perceived negatively.

Usually, it is the tendency of governmental bodies to neglect anti-fire zones when the threat of fire is forgotten. Therefore, it is argued that in order to actually maintain and embrace these zones, there must be a motivation for the community. We have seen in wildfires that one of the most effective motives for protection is to preserve property and utility. Therefore, SCFZs could replace the classic anti-fire zones as slices of land with motives for exploitation by local communities.

\section{Case Study: The Fire in Euboea}

The fire on the island of Euboea in August 2021 burnt 52,900 ha (Figure 7) including areas recognized as landscapes of high quality and biotopes characterized by Natura and Corine [71]. Interestingly, recent related studies [72] did not take into consideration that the landscapes were in danger but rather considered urbanization and development as possible threats.

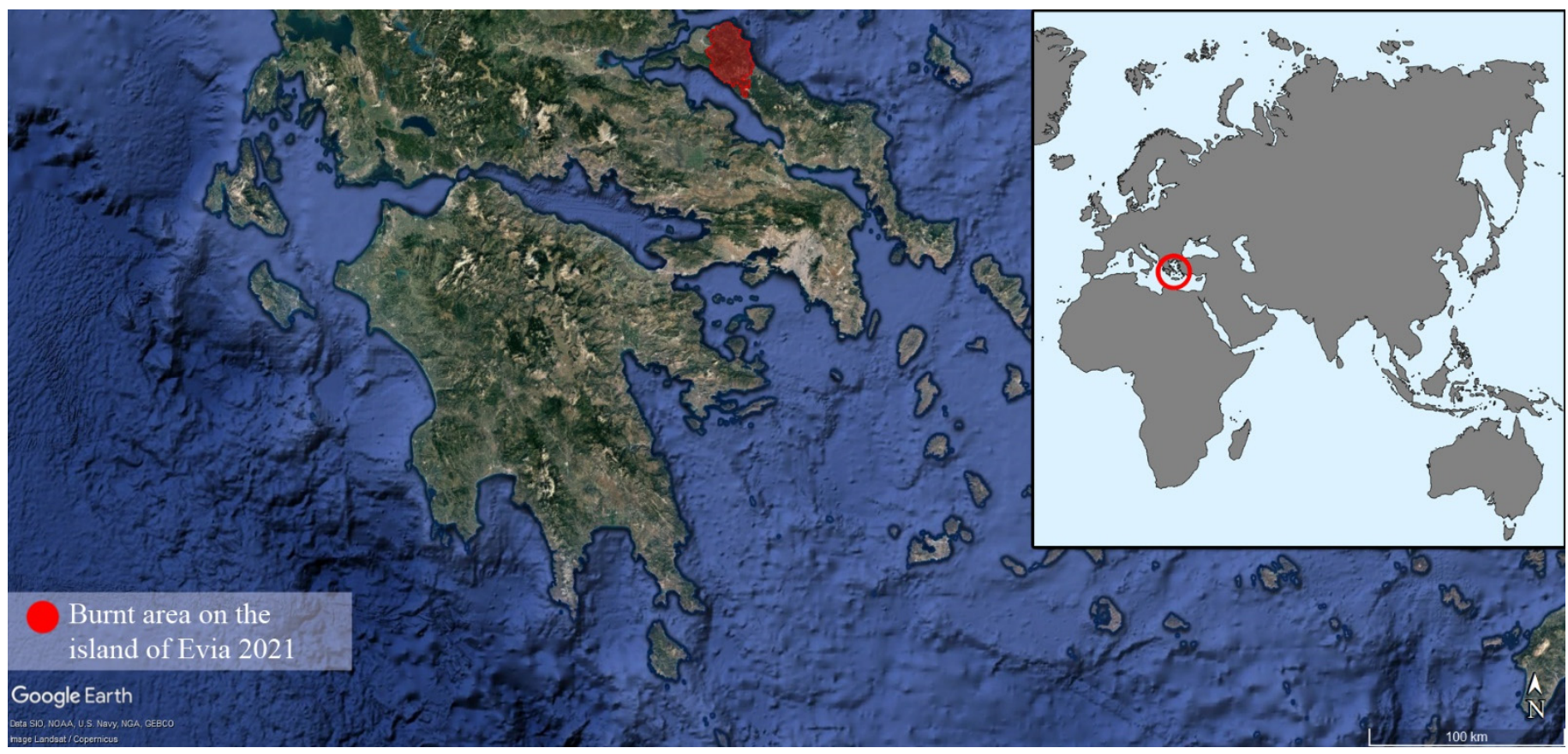

Figure 7. Burnt area on the island of Euboea 2021 [73].

The importance of the 2021 event is that the burnt area in Euboea was 47 percent of the total burnt areas in Greece, while also in 2021, the third record of burnt areas occurred (2000-2021) (Figure 8). 


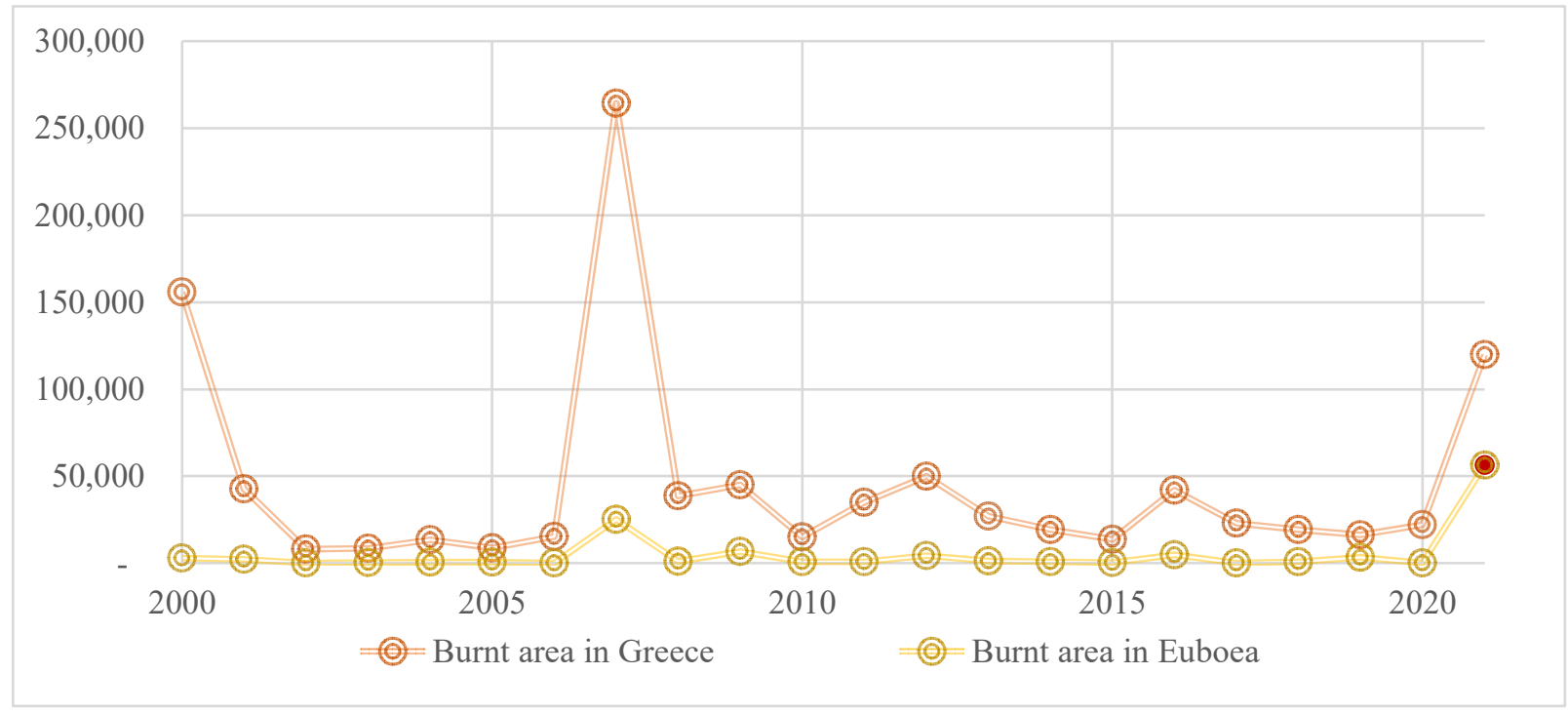

Figure 8. The evolution of wildfires in Greece and Euboea (2000-2021).

Figure 9 summarizes the evolution of fire in Euboea 3-11 August 2021 (for a more detailed description, see also Section S2, Figures S7-S16, of supplementary material [74,75]). This event was covered by the largest media organizations worldwide (Figure S19). Even though the Euboea 2021 fire was highlighted as extreme, it is interesting to note that there were smaller but similar events in the area (in the same order of magnitude, i.e., more than 20,000 ha) in 1977 and 2007 (Figure S20). Annually burnt areas in Euboea are on average $\sim 6$ percent of the total burnt areas in Greece.
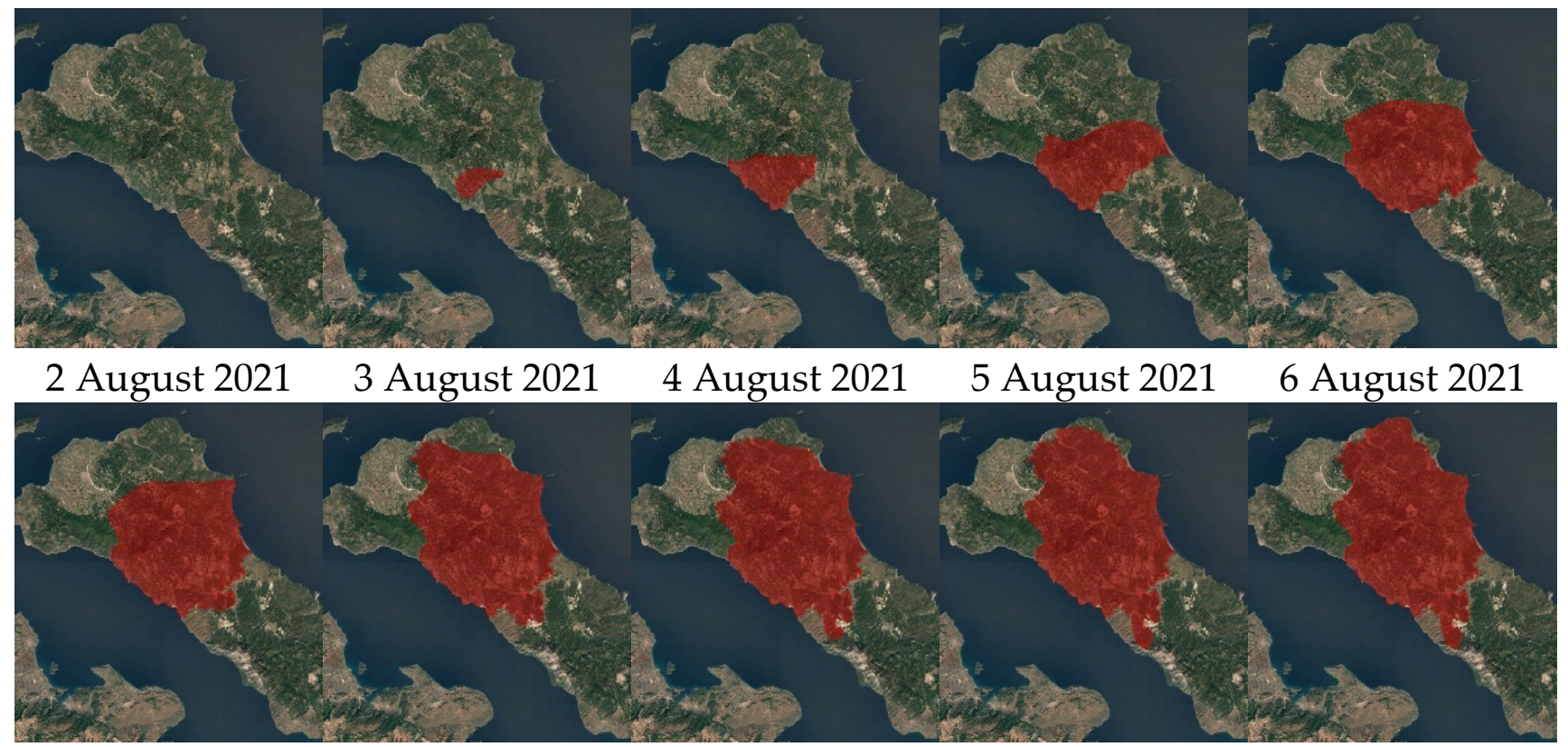

7 August $2021 \quad 8$ August $2021 \quad 9$ August $2021 \quad 10$ August $2021 \quad 11$ August 2021

Figure 9. The total area of the fire was adapted by [76,77]. The evolution of the fire, adapted graphically in Google Earth [73] by satellite imagery [78,79], calibrated by the reports of 112 Emergency Communications Service [80]. 
During 2007, only small-scale/intensity fires occurred on the island of Euboea before the large-scale high-intensity fire of 2021. Herein, this event was an expected outcome given the long-time accumulation of fuels in the forest.

\subsection{Inspecting Fires' Parameters in the Event}

Figures 10-12 show temperature and wind, both meteorological parameters, (adapted graphically by [81]) which contributed to the fire in Euboea (Figures S21 and S22) between 2 and 12 August 2021.

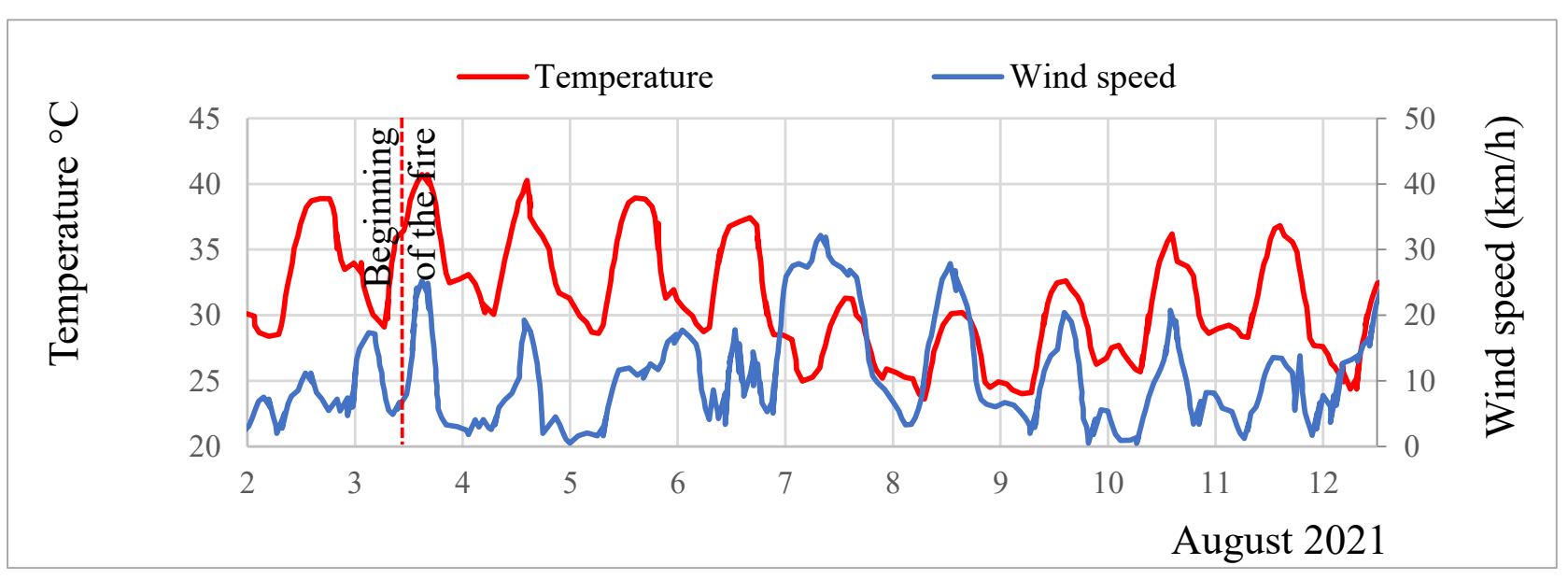

Figure 10. Temperature and wind speed in the area of Euboea [81].

The first issue to be examined in the fire triangle is temperature; we can notice that at the beginning of the fire, high values of air temperature were observed. Data from previous days also show high values of daily temperatures.

The second issue in the fire triangle is oxygen rate, which can be increased and renewed with the speed of the wind. In this fire, we did not find a correlation between the evolution of the fire and the speed or the direction of the wind.

The third issue in the fire triangle is fuels. With the digital processing of satellite images, we present the clustering of the pine trees of the wider area. The fuels in this wildfire are pine trees, and in Figure 13, we show the evolution of fire between 3 and 11 August.

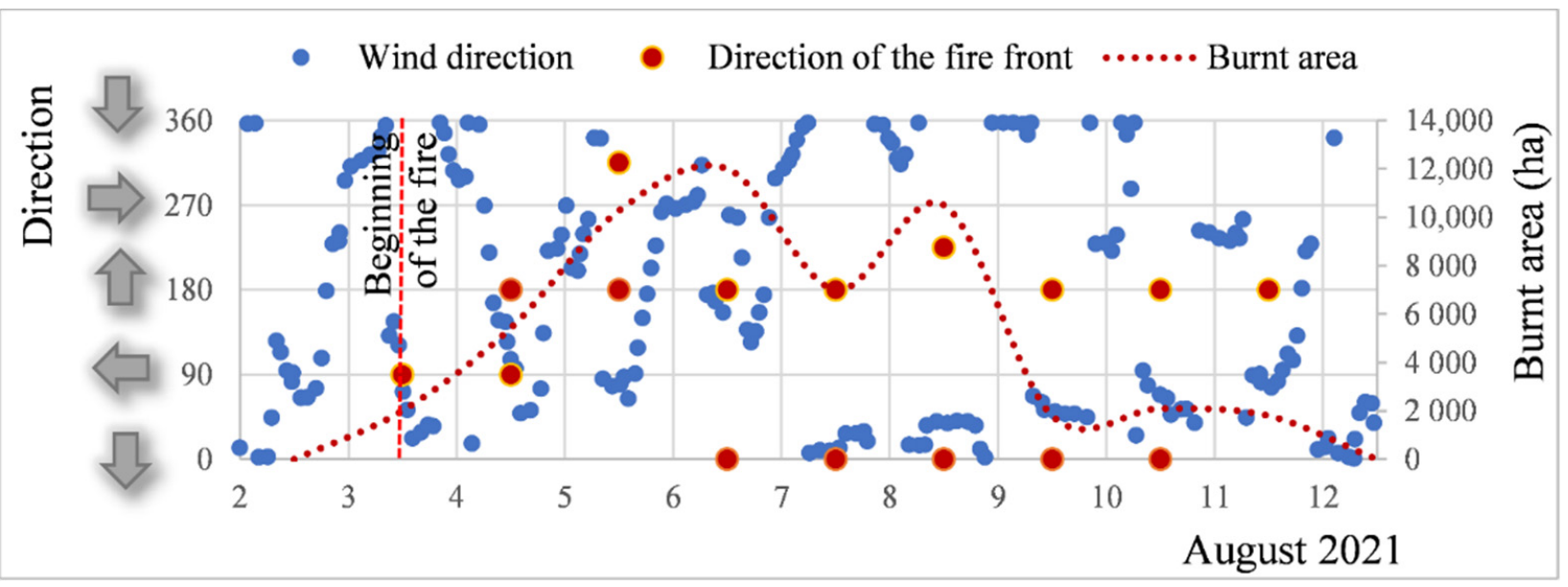

Figure 11. Wind direction (blowing to); 0, 360 North, 270 West, 180 South, 90 East [81]. 


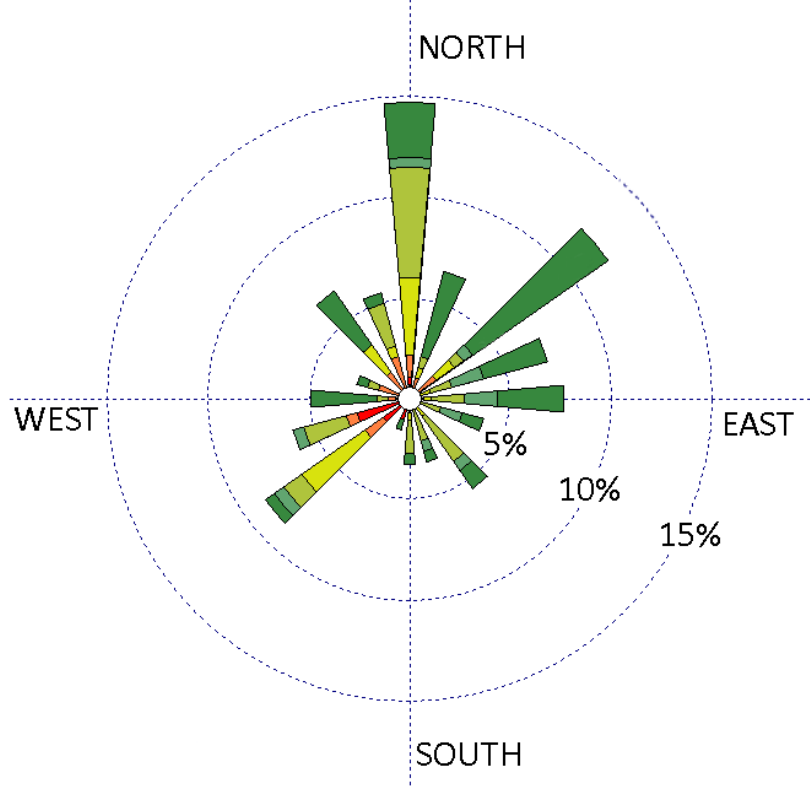

WIND SPEED $(\mathrm{km} / \mathrm{h})$

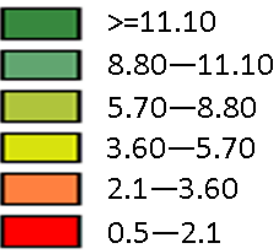

Figure 12. Wind rose diagram. Euboea 3-11 August 2021. Wind direction (blowing to) [81]. Image created by WRPLOT View [82].

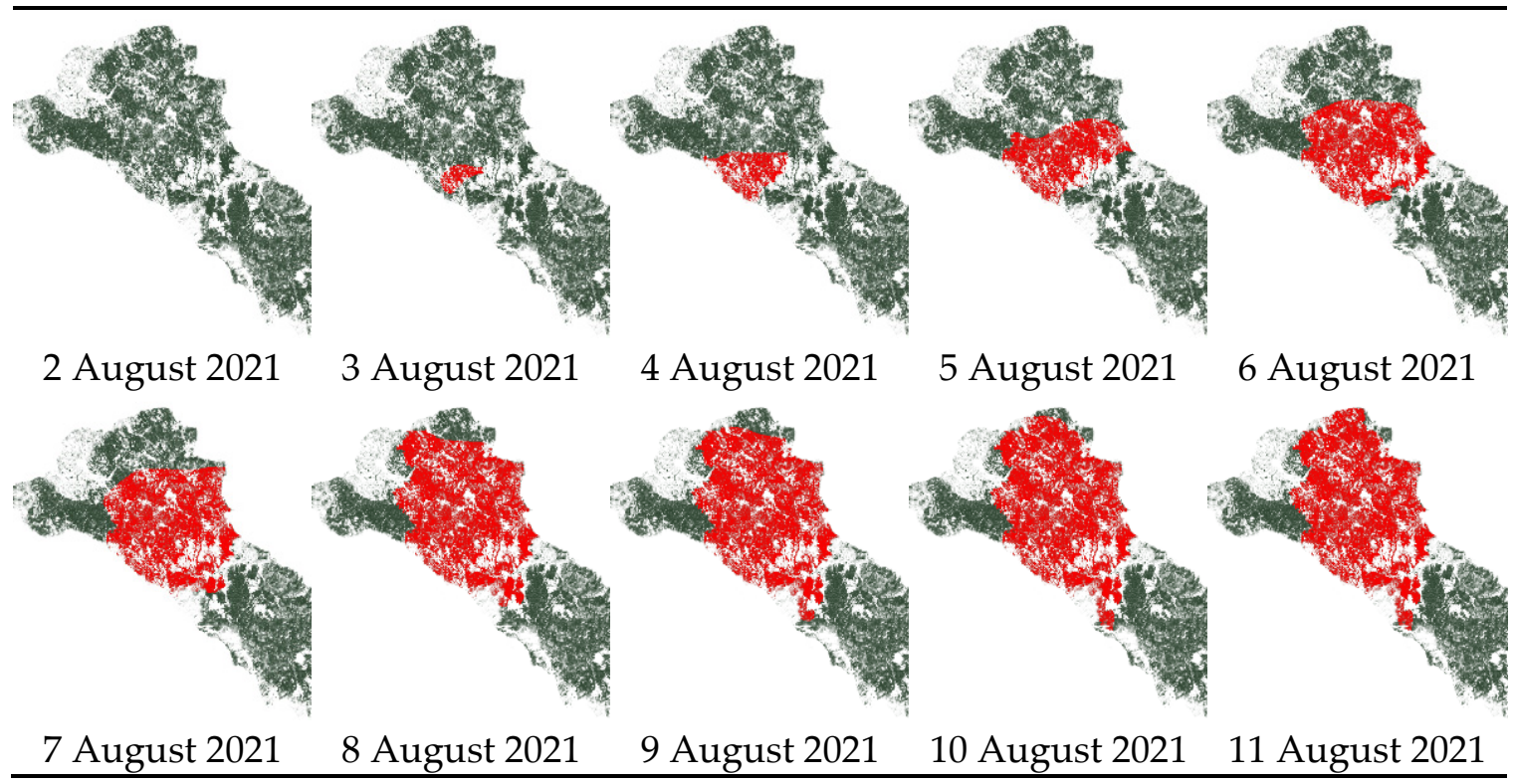

Figure 13. The evolution of fire, related to forests' clustering, calibrated by the reports of 112 Emergency Communications Service [80].

Before the fire, the forests in north Euboea were partly cultivated. As the last big fire happened more than 20 years ago, the forest had herb and shrub layers under the pine trees which helped the evolution of the fire. Fortunately, there was no litter spread in the area. However, there were secluded places with litter that were burned. In addition, a cold wave named Medea happened between 13 and 16 February 2021 [83]; many branches and trees were broken, and no one took care to pick them up [84]. This flammable material dried up in the summer and was a supplementary layer that favored the spread of the fire.

A closer look at the fire shows that fire is driven where the pine trees were clustered.

Herein we can assume that forest clustering was the most important issue for the evolution of this fire. 
The fire had a partitioned zone of forest in its south part; therefore, in the first three days, fire burned mostly the northern, western, and eastern areas. On 6 August, fire was driven by two clustered forest areas in the east-south and west-south parts of the fires' front and connected to the south clustering. This cost $\sim 8000$ ha more of burnt areas.

Analyzing the daily evolution of the clustering of the fire front (Figure 13) and the evolution of the clustering of thermal detection by the satellite imagery (Figure 14 and Figures S17 and S18 in Supplementary Material [85]), we see that both are related to the evolution of fires and the burnt area (Figure 13). This is also verified by the estimated correlation through the climacogram integral (Figure 15). The climacogram integral also validates the clustering of fire and the daily burnt areas. Figures 16 and 17 show burnt areas in the fire incident.
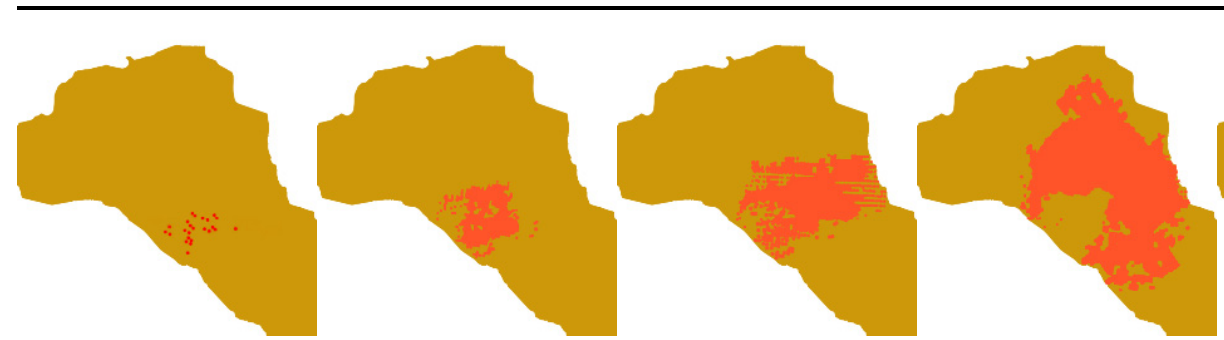

4 August 2021

5 August 2021

6 August 2021

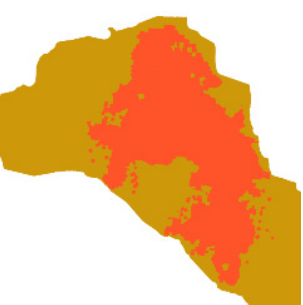

3 August 2021
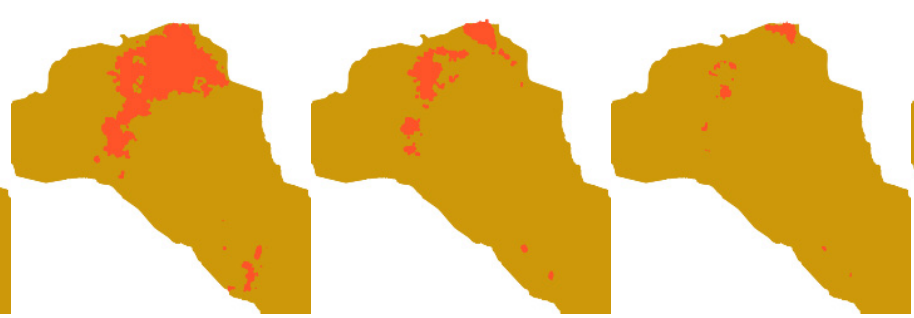

7 August 2021

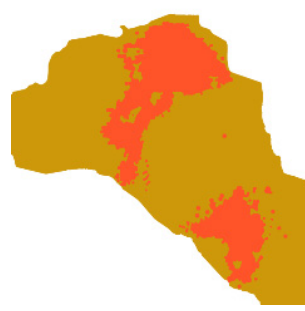

9 August 2021

10 August 2021

11 August 2021

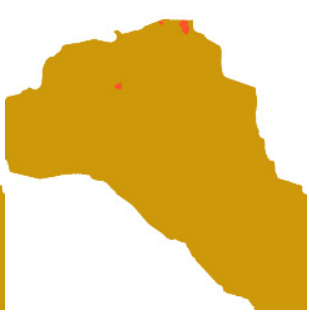

Figure 14. The intensity of fire as detected by satellite imagery $[78,79]$ calibrated by the reports of 112 Emergency Communications Service [80].

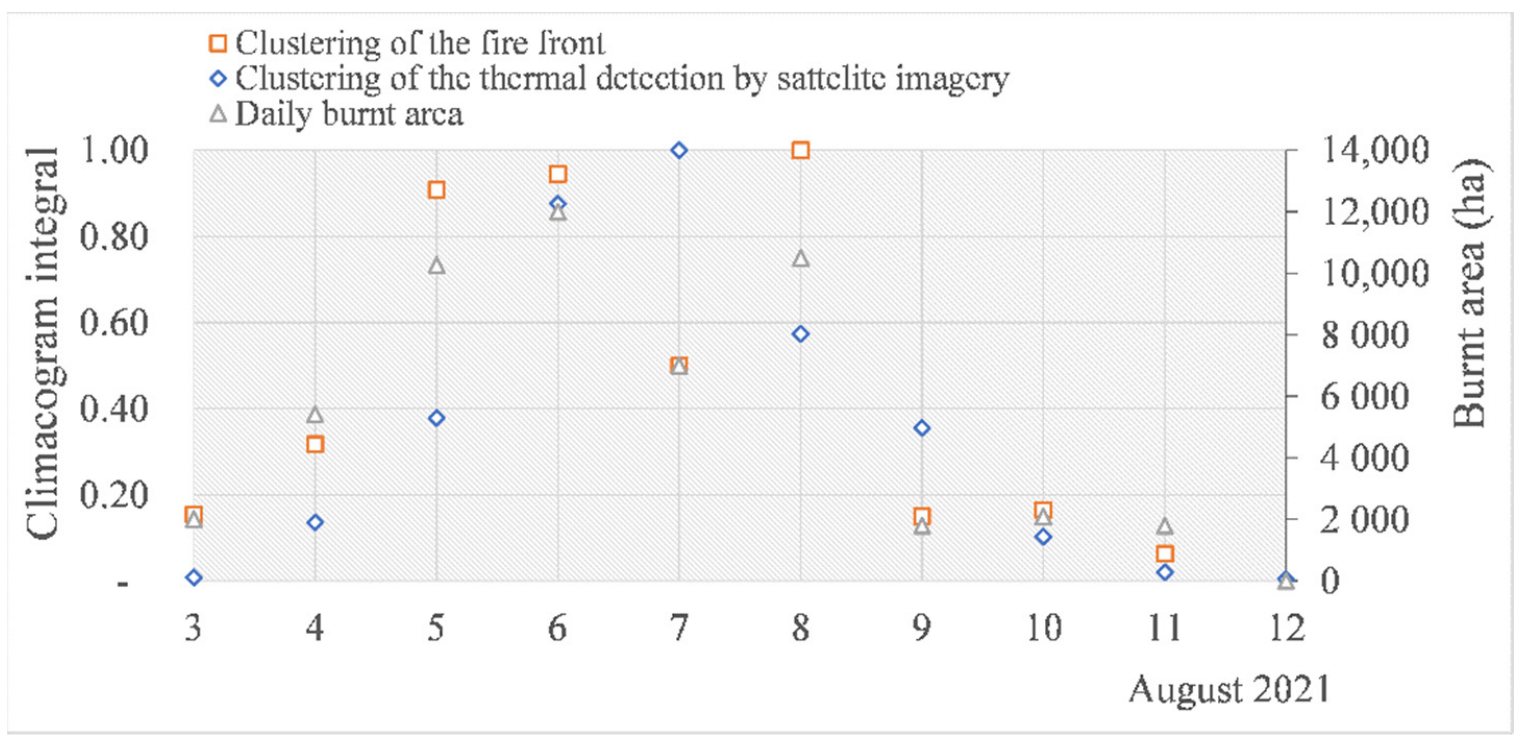

Figure 15. Evolution of clustering of fire front, thermal detection, and daily burnt area. 


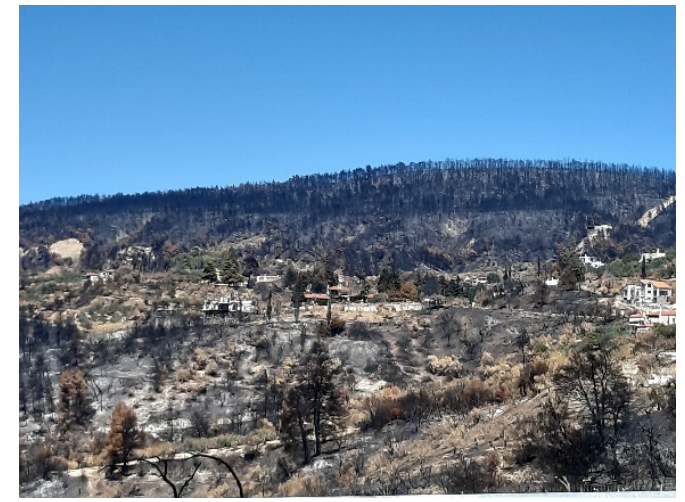

(a)

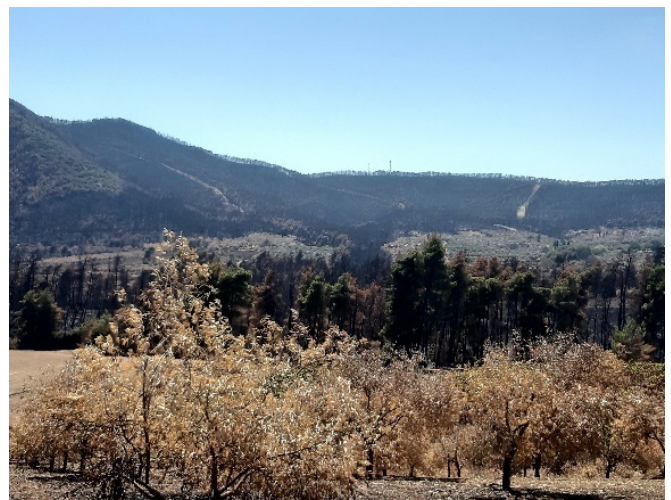

(b)

Figure 16. (a) Burnt area. (b) Burnt areas with anti-fire zones.

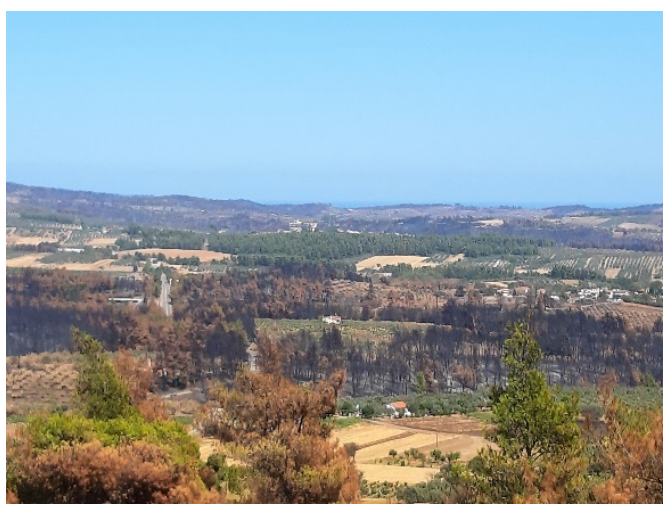

(a)

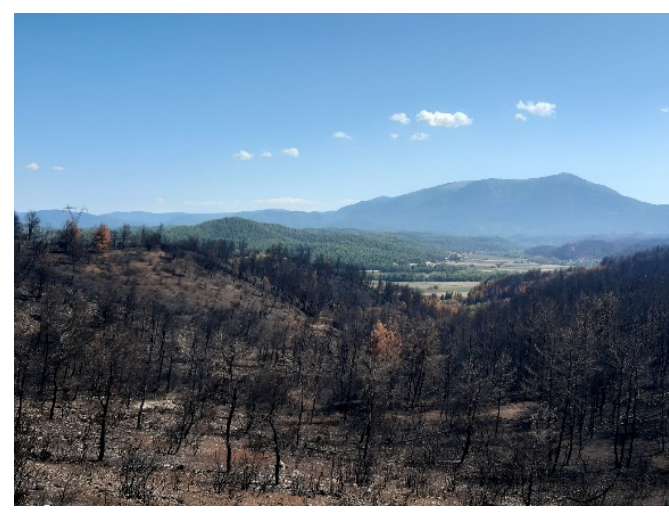

(b)

Figure 17. (a) Not burnt areas in the middle, forest without connection with the rest of the forest area (SaIs). (b) Burnt areas. In back, the flat land of Krya Vrisi which stopped the fire.

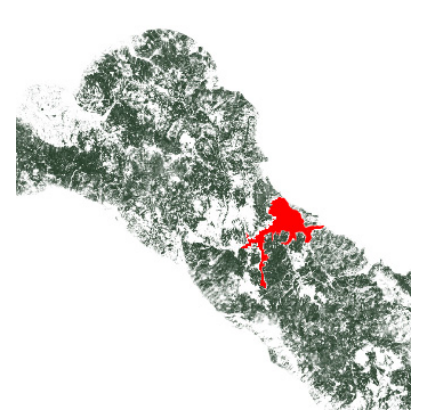

(a)

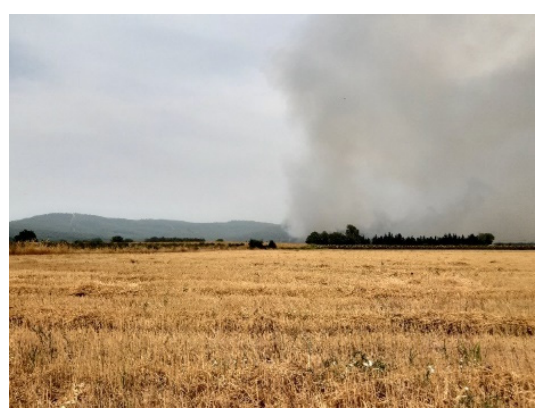

(b)

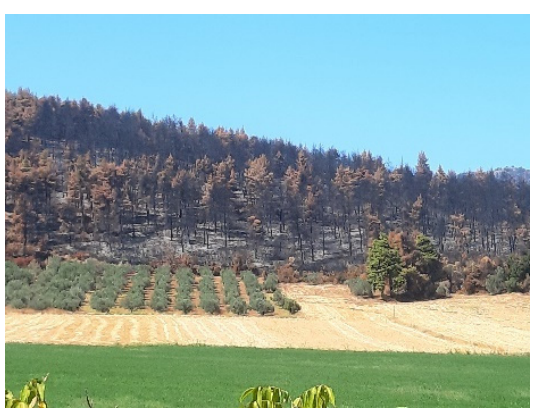

(c)

Figure 18. (a) The flatland of Krya Vrisi. (b) The flatland of Krya Vrisi during the fire. (c) The flatland of Krya Vrisi after the fire.

The evolution of fire was also supported by the intense anaglyph of the area.

The linear flatland of Krya Vrisi divides the island of Euboea and contributed to containing the fire and restricting the evolution of the front of the fire (Figures 18 and 19). 


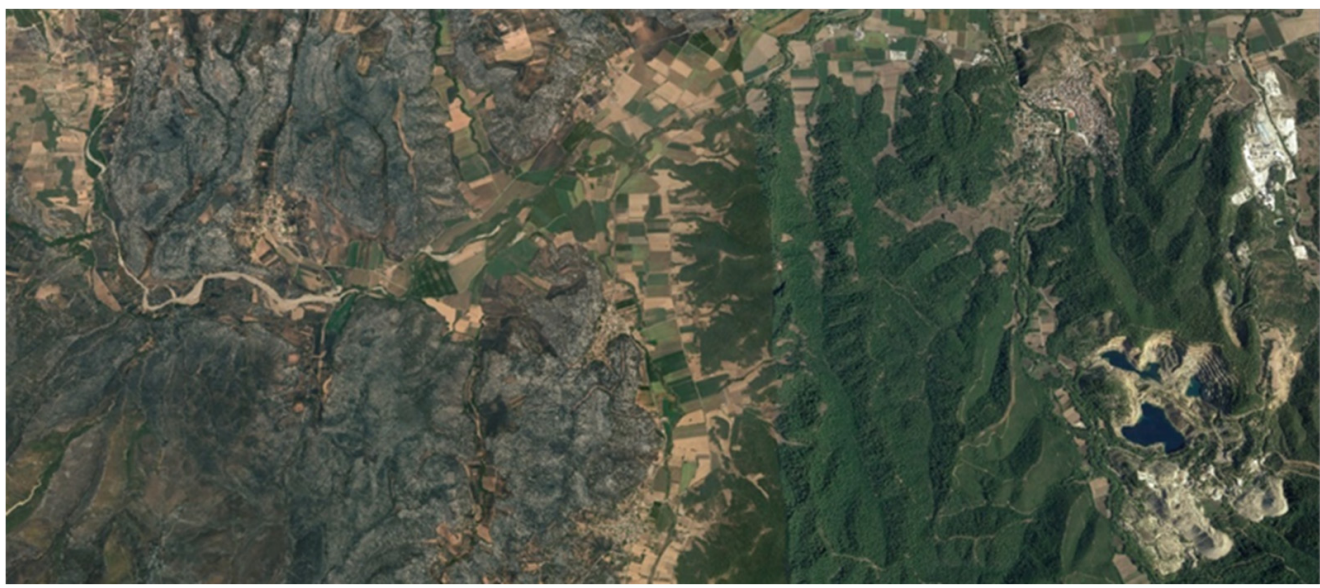

Figure 19. The flatland of Krya Vrisi (center of the figure). The area of the fire (left), forests untouched by the fire (right). Map form Google Earth [73].

\subsection{Local Communities and the Forest}

Before the fire, about 580 families in north Euboea exploited the forest collecting resin, and about 80 families were working in logging. Others were beekeepers or had olive trees. It is estimated that 50\% of the Greek production of resin (3000 tons per year) and 65\% $(10,000$ tons per year) of the Greek production of pine tree honey were lost. In addition, 9000 beehives were destroyed or suffered severe damage [86-89].

Examining the livestock and the beehives of the area (Figure 20), we see that about $88 \%$ of these activities rely on the forest. Even the coops were out of villages, inside the forest, and many of them were burnt.

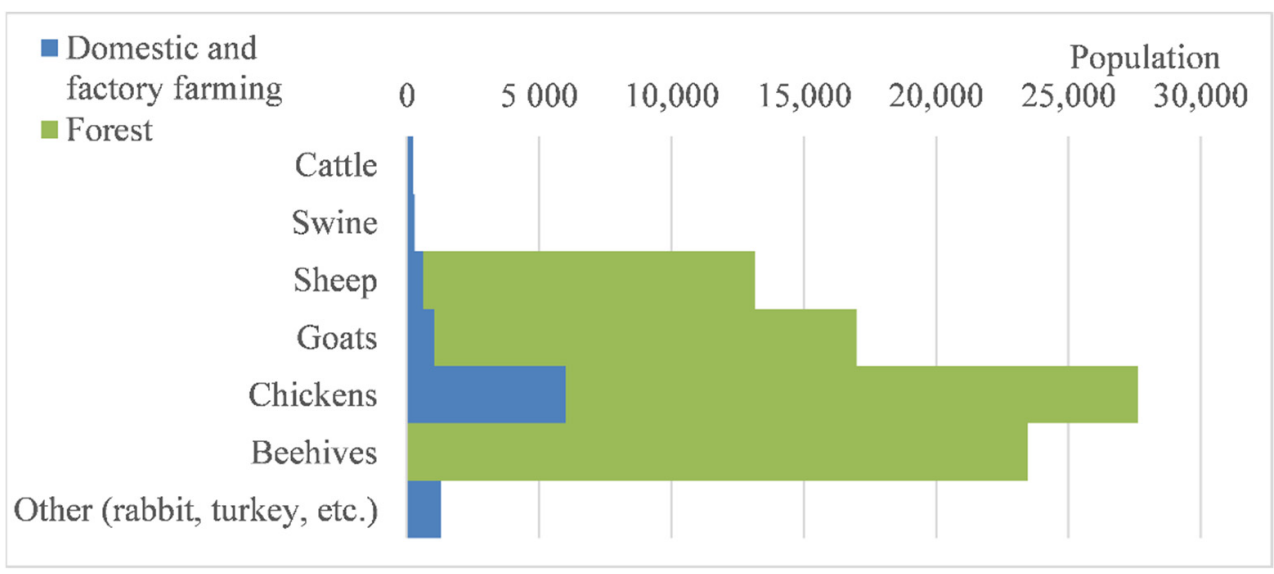

Figure 20. The livestock and the beehives of the municipalities of Istiaia-Edipsos and Mandoudi-Agia Anna-Limni by the census 2019 [90].

It is clear that the forest constitutes wealth for the local community, and hence its destruction is an economic disaster for the community, even for inhabitants whose properties were not affected by the fire.

After the wildfire of 2021, the Greek state introduced a new law to indemnify the lost properties of inhabitants [91]. Unfortunately, this law does not answer the question: Can people recover the sustainable wealth that they have lost?

As people have now lost the forest area they used for cultivation, collecting resin, or logging after this catastrophe, our purpose is to give SCFZs to people to promote sustainable development, which could be supported through the water-food-energy nexus [92].

Products or commodities provided by these forests constitute only a part of their value for local communities. There is more than those products in benefit of people, 
i.e., environmental services (clean water, air, recreation, habitat conservation, etc.), that should be considered in any forest conservation strategy. Moreover, local communities must be aware of these services and value them as incentives for forest conservation.

Livestock could accelerate the recovery process. However, the Greek state protects the environment according to the Greek Constitution [93], and livestock is considered a threat to the forests. The Greek state forbids livestock in burnt areas according to the legislative decree of 86/1969 [94] which is replaced by article 60 of Law 4264/2014 [95] that mentions:

An order forbidden grazing, issued ex officio by the forest service, prohibits the grazing of any animal in an area that has been declared reforestable.

In other words, inhabitants that were fortunate that their livestock survived this fire, instead of grazing their livestock, will probably be forced to increase the cost for animal feeding since their livestock cannot be moved to the burnt area, or they will face a penalty that depends entirely on the chief of the local forest service. Therefore, inhabitants must quit feeding their livestock in the burnt area as, if they have to pay for the feed, this activity will be damaging.

Generally, there is a widespread belief that livestock is a threat to the forest ecosystem. However, modern studies support the opposite [96-98]. An introduction to this recovery process is given by Savory and his method "Managing the complexities of land \& livestock" [99].

Therefore, we give an example of SCFZs that were designed following the faint clustering of the forests in a wider area of north Euboea. The partitioning is presented assuming that the forest is exploited and cultivated and livestock is grazing (Figure 6). The firebreaks as strips of land that has been cleared of all trees (usually linear and small) are areas that can stop fire without human intervention only $46 \%$ of the time [100]. However, these strips are prone to erosion and are not cost-effective because they need to be cleared at least once a year, and finally, these zones are aesthetically unpleasant.

Obviously, the partitioning process will be annoying as the natural forests are pristine and highly perceived landscapes. However, we have to consider that in many cases, the alternative is that the forest could be completely burned and then require as long as 20 or 30 years for its rebirth. We should thus consider whether certain but small-scale impacts on forests may be preferable over a potential but large-scale disaster. It should also be taken into account that the communities developed around forests exploit them and take advantage of their natural resources. Thus, a large-scale destruction of the forest can be catastrophic and can even lead to the collapse of such communities. Therefore, we have to consider more how to support the inhabitants and enjoy the landscape of the forest more often than every 30-40 years. In addition, we have to consider that the society will grow along with the forest but with a high risk of destruction.

Another question we have to ask is how in Krya Vrisi this partitioning zone area that stopped the fire was created.

One part of the land of Krya Vrisi was property of big landowners, and another was unexploited (forests, swamps) until the early 20th century. This land was given to immigrants who came to Greece [101] from the Asia Minor catastrophe in 1922 to cultivate it [102] (Figure S23).

This area is an example of how, 100 years earlier, the Greek state, without the slightest guilt about deforestation, gave people wealth (land) to survive, which was also used for protection of the forest recovery process.

\subsection{General Aspects}

It is clear that the recovery process is affected by political aspects.

Therefore, we could expect that a hypothetical Marxist would find a way to make the inhabitants state employees adapted for the new needs (for example, the cultivation or the forests to grow faster) $[103,104]$. A Keynesian [105] would propose the construction of large public infrastructures in the area where inhabitants could have jobs. A neoliberal $[106,107]$ would expect the capital to give a solution exploiting the desperate inhabitants and the 
present low value of the environment. "Green" points of view (e.g., "degrowth" [108,109] or "prosperity without growth" [110]) would propose a "do nothing" solution and leave the forest to be reborn naturally, with a Malthusian perception [111,112], as they consider people as parasites of nature and development as a useless consumption and production of wastes.

In our viewpoint, the key is the discovery and the creation of sustainable wealth and its distribution to people. Themistocles Xanthopoulos defined this as "endogenous productive reconstruction" [8-10]. Sustainable wealth means that people could survive in their land, producing their own wealth, which will be sustainable through time with the potential for growth. As primary wealth, we consider the support of the energy-water-food nexus.

Therefore, we propose a forest management strategy based on the creation of SCFZs. The SCFZs require, other than the creation of an anti-fire zone, free of trees, the provision of rights of use to inhabitants and the integration of participatory decision-making processes to strengthen the potential for co-production of the land uses to be introduced in the SCFZs. This is inspired by practices dating as long as 100 years back. Examples for land uses to be introduced in the SCFZs could be: (i) use as fields for the support of existing livestock, for the re-organization and development of new livestock uses in the SCFZ spaces, (ii) cultivation of areas of the SCFZs or installation of auxiliary infrastructure for the support of existing processes for the utilization of forest produce, (iii) installation of renewable energy infrastructures or renting the areas of SCFZs if capital for such investments is not available in local communities, and (iv) investigation for the potential of installation of small-scale water infrastructures, such as small reservoirs or small hydropower dams.

\subsection{Three-Dimensionally Printed Constructions for Cultivation Areas or Corrals}

In order to enrich SCFZs according to the concept of "endogenous productive reconstruction", 3D-printed construction made of eco-friendly materials could be installed. This innovative technology has many benefits that can contribute to the sustainability of these areas and strengthen their economic value.

The positive impact of this application is faster results of on-site construction, less waste, reduced labor, and more sustainable structures compared with traditional construction. In addition, 3D printing allows for more creative freedom in architecture which can be better harmonized with the landscape $[113,114]$.

Three-dimensional printing seems to give the expected spaces a proper timetable as a quick-build cell could be constructed from raw earth [115]. The idea of combining advanced technology and local material such as earth has many benefits:

- Fast collection of the material when combining materials with local soil.

- Construction without the need for scaffolding.

- Raw earth is eco-friendly and biodegradable and can produce sustainable constructions. The utilization of renewable materials is necessary nowadays.

- The construction can be inhabited almost immediately.

- Corral, warehouse, or shelter equipment such as sitting benches, workbenches, bed bases, and watering cans could be printed during the process of the printing of partition walls.

\section{Discussion}

The claim that wildfires have become uncontrollable due to climate change is challenged by real fire data from the USA, Canada, and Mediterranean countries. A more pragmatist approach for the mitigation of wildfires is proposed, with forest protection planning and policy at its core.

In the direction of enforcing forest management, we carried out an investigation of a more holistic forest protection logic that prioritizes the mitigation of local fires in combination with a social system for forest partitioning. The idea behind this is that continuous small-scale management of forests can have advantages over massive isolated efforts after disasters. The prioritization of forest handling and mitigation of local fires 
seems to prevail in terms of prevention of large-scale disasters; as the proverb says, relevant policy and practice often "cannot see the forest for the trees". Thus, unfortunately, it is often noticed that the state tends to develop protection measures only after major catastrophes. In the case of Greece, for example, this can be observed in the evolution of the legislation of the Forest Service for cutting pine trees. Until the 2021 Euboea fire, cutting of pine trees even in private property was forbidden. The burning of more than 1000 houses in Euboea [116] within or in the proximity of areas with high densities of untended pine trees has arguably incited the emergence of plans of changes in policy that would legalize the cutting of trees [117].

In the examined case study of the 2021 fire of Euboea, the fire burned an area of 52,900 ha of the north part of the Island. The main part of the forest that was not burned from the fire (red rectangle in Figure 21a) is about 30,000 ha in the south part of Krya Vrisi. It is a highly clustered forest that can potentially be endangered by future wildfires. The spatial clustering of this forest is indicated in Figure 21b-d. Unfortunately, at this point, there is no reason to expect that a wildfire of a similar scale would not threaten this area as well. Yet north Euboea is not an exception. Similar threats are present in various forests in Greece as the population is clustering in big cities (Figure 22).

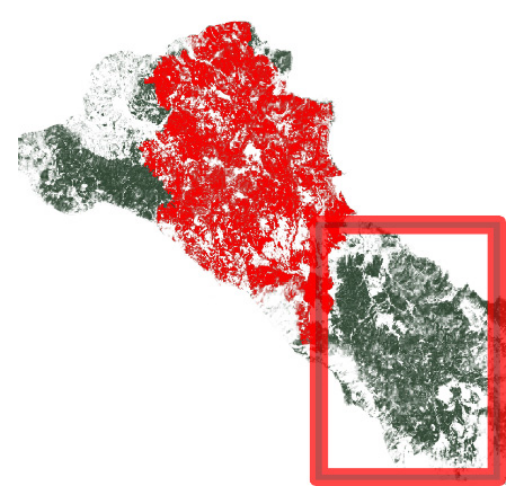

(a)

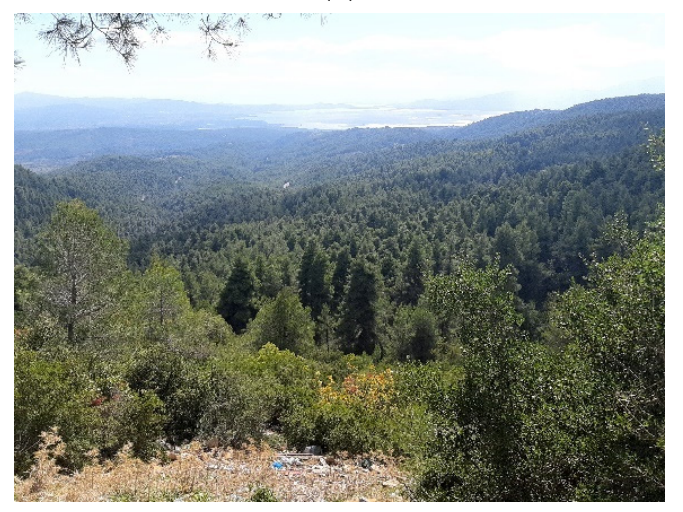

(c)

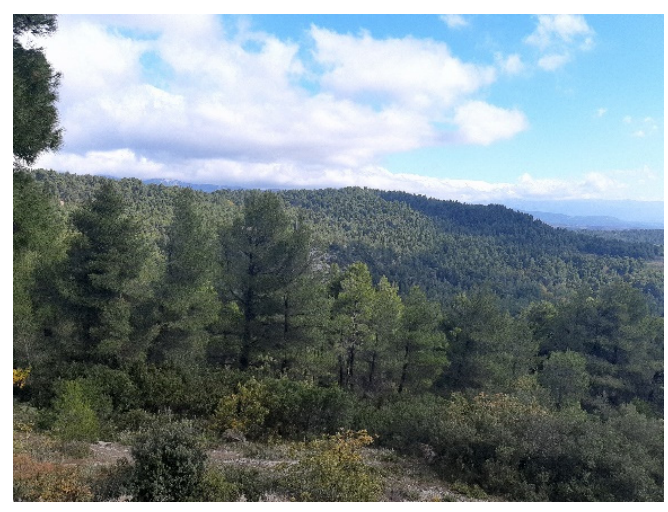

(b)

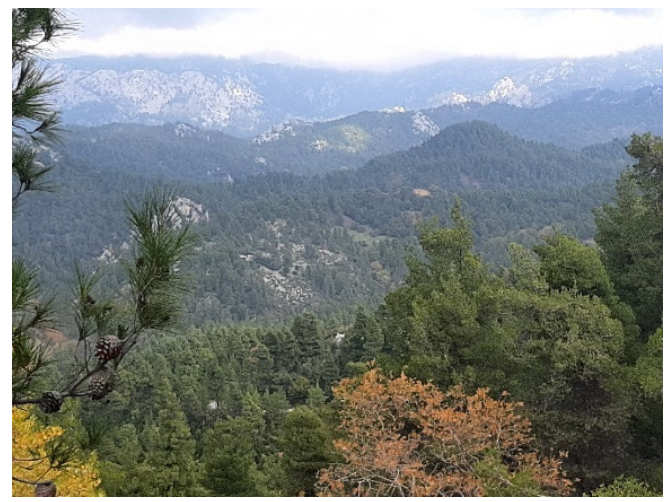

(d)

Figure 21. (a) Map of north Euboea. The burnt forest is presented in red, and the unburnt south part of Krya Vrisi is presented inside the red rectangle. (b-d) Photographs of the forest in the south part of Krya Vrisi.

In their study about land-use change of forests and wooded land correlation with large and frequent wildfires, Ascoli et al. [118] concluded that:

... land abandonment have probably increased fire proneness at national scale by expanding shrub and tree encroachment, and thus increasing fuel connectivity and fuel build-up. Therefore, we urge for a greater integration between fire management and rural development policies. 


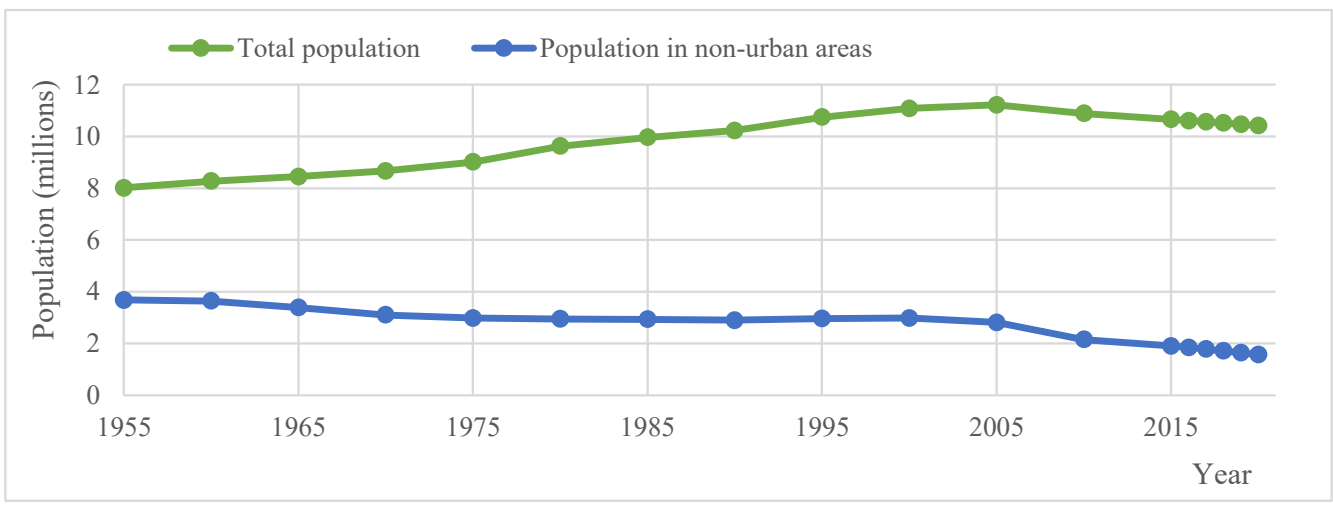

Figure 22. Total population of Greece and population in non-urban areas 1955-2019 [119].

With this study, we tried to emphasize the society's cohesion and the activation of people in the forest as a way of protection. This aspect is also emphasized by WWF as the primary measure for the protection of forests [120]. However, we noted that people forget the threat, and they do not learn lessons from previous disasters (Figure S18). Therefore, we proposed a way in which the memory of the past events can be integrated into landscapes, promoting the capability of protection from future events.

The design of SCFZs needs an analytical study, field research, and detailed adoption of ecological and geomorphological criteria with a geographic information system (GIS). As SCFZs and SaIs might imply important risks to habitat connectivity, ecological bridges for the connection ecosystem should be designed and proposed. In addition, geometrical standards for the design of the partitioning should be estimated as they are important because they affect the occurrence of some ecological processes, other than wildfires; moreover, no considerations are made on edge effects, which might lead to forest fragmentation issues.

In addition, redistribution of land use presupposes that an economic-technical study of the required activities and innovative political decisions should also be conducted.

\section{Conclusions}

Our proposal for the protection of forests is the sustainable partitioning of forests through the design and creation of SCFZs. The SCFZs can prevail over common anti-fire zones by providing motives for maintenance through the provision of some of the resources of the forest to people that live near it. We believe that this type of modification can prevail over conventional anti-fire zones and could promote a sustainable development strategy that is synergistic to the protection of the forests and to an "endogenous productive reconstruction" which was the dream of Themistocles Xanthopoulos [8-10]. Arguably, in the examined case of Euboea's wildfire of 2021, partitioning of the forest could have reduced the fuel to support the fire and could have put the fire more easily under control.

In regard to the discussion of the land uses that can be applied in SCFZs, we have to note that restrictions of grazing livestock in burnt places, such as those enforced by Greek laws, are not in line with modern literature. Recent studies showcase that livestock can actually benefit forests in their process of regeneration.

As part of the policy considerations of this study, it has to be noted that planning mitigation measures for the development of forests is a long-term procedure that is expected to be verified after 10-20 years. Decision makers (that usually live in the capital city) often forget that a lot of people to whom forests were directly associated to their livelihoods have lost everything and are now living as "immigrants" in their own property and land. The SCFZs aspire to be a method to assist these inhabitants to remain in their land, exploiting the resources and potential wealth of the forest in modern ways and, meanwhile, also creating the necessary partitioning of the forest that is required for its protection.

Further research has to be undertaken to identify the partitioning criteria for the creation of the SCFZs and formulate guidelines for their design. A key point is that SCFZs 
should be considered as ecologically functional units, as the functionality of SCFZs in maintaining ecosystem processes would also contribute to their recovery process and thus further serve their sustainability.

Supplementary Materials: The following supporting information can be downloaded at: https: / / www.mdpi.com/article/10.3390/conservation2010013/s1, which contains the following sections (with additional illustrations): Section S1: Clustering as a Growth Process; Section S2: The Evolution Burnt Areas in Google Earth; Section S3: The Evolution of Fire by Satellite Views; Section S4: Additional Documentary Information.

Author Contributions: Conceptualization, G.-F.S.; methodology, G.-F.S.; validation, G.-F.S.; formal analysis, G.-F.S.; investigation, G.-F.S., I.B. and E.F.; data curation, G.-F.S.; writing-original draft preparation, G.-F.S., R.I., I.B., E.F., P.D., T.I., D.K. and N.D.L.; writing-review and editing, T.I., D.K. and N.D.L.; visualization: G.-F.S.; supervision, N.D.L.; project administration, N.D.L. All authors have read and agreed to the published version of the manuscript.

Funding: This research was funded by European Union funds grant number 101007595.

Institutional Review Board Statement: Not applicable.

Informed Consent Statement: Not applicable.

Data Availability Statement: The databases that were used are referred to in detail in the citations given in the text and are publicly available. Data depicted in Figure 20 were sent by e-mail to the first author by the Hellenic Statistical Authority. Analytical data about the affected area of the fire in Euboea were sent by e-mail by the National Observatory of Athens (NOA).

Acknowledgments: G.-F.S., E.F. and N.L. were supported for this research by the ADDOPTML project "ADDitively Manufactured OPTimized Structures by means of Machine Learning" (No: 101007595) belonging to the Marie Skłodowska-Curie Actions (MSCA) Research and Innovation Staff Exchange (RISE) H2020-MSCA-RISE-2020. We thank Andreas Efstratiadis for his useful comments. G.-F.S. acknowledges his daily contact with the late Themistocles Xanthopoulos in preparing the presentation of his book "Requiem with Crescendo" and in particular his conversations about the political and environmental aspects of the fire in Euboea. G.-F.S. proposed him to work together this paper, but as he suddenly passed away, he dedicates his humble work to the memory of his beloved friend, mentor, professor, dean, rector, and vice-minister Themistocles Xanthopoulos.

Conflicts of Interest: The authors declare no conflict of interest.

\section{References}

1. Pyne, S.J. Fire: Nature and Culture; The University of Chicago Press: Chicago, IL, USA, 2013.

2. Reborn from Ashes: The Alvares Project. Available online: https://www.rsm.nl/cdc/case-catalogue/detail/845-reborn-fromashes-the-alvares-project/ (accessed on 5 February 2022).

3. Climate Change Indicators: Wildfires. Available online: https://www.epa.gov/climate-indicators/climate-change-indicatorswildfires (accessed on 5 February 2022).

4. Koutsoyiannis, D. Broken line smoothing: A simple method for interpolating and smoothing data series. Environ. Model. Softw. 2000, 15, 139-149. [CrossRef]

5. Xanthopoulos, G.; Delogu, G.M.; Leone, V.; Correia, F.J.M.; Magalhães, C.G. Firefighting approaches and extreme wildfires. In Extreme Wildfire Events and Disasters; Tedim, F., Leone, V., McGee, T.K., Eds.; Elsevier Inc.: Amsterdam, The Netherlands, 2020; pp. 117-132.

6. Ribeiro, L.M.; Viegas, D.X.; Almeida, M.; McGee, T.K.; Pereira, M.G.; Parente, J.; Xanthopoulos, G.; Leone, V.; Delogu, G.M.; Hardin, H. Extreme wildfires and disasters around the world: Lessons to be learned. In Extreme Wildfire Events and Disasters; Tedim, F., Leone, V., McGee, T.K., Eds.; Elsevier Inc.: Amsterdam, The Netherlands, 2020; pp. 31-51.

7. Moreira, F.; Viedma, O.; Arianoutsou, M.; Curt, T.; Koutsias, N.; Rigolot, E.; Barbati, A.; Corona, P.; Vaz, P.; Xanthopoulos, G. Landscape-wildfire interactions in southern Europe: Implications for landscape management. J. Environ. Manag. 2011, 92, 2389-2402. [CrossRef] [PubMed]

8. Xanthopoulos, T. Requiem with Crescendo? Homo Sapiens the Ultimate Genus of Human; National Technical University of Athens: Athens, Greece, 2017; Volume A. (In Greek)

9. Xanthopoulos, T. End of 15th Century-Beginning of 21st Century. In Requiem with Crescendo? Homo Sapiens the Ultimate Genus of Human; National Technical University of Athens: Athens, Greece, 2020; Volume B. (In Greek) 
10. Xanthopoulos, T. Tracking the Exit in 21st Century. In Requiem with Crescendo? Trapped in the Despotisms and Whirlpools of the Artificial Pangea and Panthalassa; National Technical University of Athens: Athens, Greece, 2020; Volume C. (In Greek)

11. AR6 Climate Change 2021: The Physical Science Basis. Available online: https://www.ipcc.ch/report/ar6/wg1/ (accessed on 5 February 2022).

12. Doerr, S.H.; Santín, C. Global trends in wildfire and its impacts: Perceptions versus realities in a changing world. Biol. Sci. 2016 371, 20150345. [CrossRef] [PubMed]

13. Shifting Wildfire Trends and Management Implications for the Wildland Urban Interface in the Twenty-first Century. Available online: https:/ / www.intechopen.com/chapters/72916 (accessed on 5 February 2022).

14. DellaSala, D.A. Emergence of a New Climate and Human-Caused Wildfire Era for Western USA Forests. In Reference Module in Earth Systems and Environmental Sciences; Elsevier: Amsterdam, The Netherlands, 2018. [CrossRef]

15. Jurvélius, M. Health and protection Forest Fires (Prediction, Prevention, Preparedness and Suppression). In Encyclopedia of Forest Sciences; Elsevier: Amsterdam, The Netherlands, 2004; pp. 334-339.

16. National Interagency Fire Center. Available online: https://www.nifc.gov/sites/default/files/document-media/TotalFires.pdf (accessed on 5 February 2022).

17. Forestry and Fisheries. Available online: https://www2.census.gov/library/publications/1975/compendia/hist_stats_colonial1970/hist_stats_colonial-1970p1-chL.pdf?fbclid=IwAR2aJgVV-ZWfZJbtw9QvAZGo3_ZGxaz74DJdOdmtAvbLV2DUp8H0M5 epOwE (accessed on 5 February 2022).

18. Field, C.B.; Mortsch, L.D.; Brklacich, M.; Forbes, D.L.; Kovacs, P.; Patz, J.A.; Running, S.W.; Scott, M.J. North America. Climate Change 2007: Impacts, Adaptation and Vulnerability. Contribution of Working Group II to the Fourth Assessment Report of theIntergovernmental Panel on Climate Change; Parry, M.L., Canziani, O.F., Palutikof, J.P., van der Linden, P.J., Hanson, C.E., Eds.; Cambridge University Press: Cambridge, UK, 2007; pp. 617-652. Available online: https://www.ipcc.ch/site/assets/uploads/2018/02/ar4-wg2 -chapter14-1.pdf (accessed on 5 February 2022).

19. Evaluating Past, Current and Future Forest Fire Load Trends in Canada. Available online: https://www.ccfm.org/wp-content/ uploads/2013/08/2-Fire-Load-Trends.pdf (accessed on 5 February 2022).

20. San-Miguel-Ayanz, J.; Durrant Houston, T.; Boca, R.; Libertà, G.; Branco, A.; De Rigo, D.; Ferrari, D.; Maianti, P.; Artes Vivancos, T.; Costa, H.; et al. Forest Fires in Europe, Middle East and North Africa 2017, EUR 29318 EN; Publications Office of the European Union: Luxembourg, 2018; ISBN 978-92-79-92832-1.

21. Hellenic Fire Service Database. Available online: https://www.fireservice.gr/el_GR/synola-dedomenon (accessed on 17 January 2022).

22. European Forest Fire Information System (EFFIS) Database. Available online: https:/ / effis.jrc.ec.europa.eu/applications/dataand-services (accessed on 5 February 2022).

23. Tsagari, K.; Karetsos, G.; Proutsos, N. Forest Fires in Greece 1983-2008, Institute of Mediteranean Forest Ecosystems, WWF, National Institute of Agriculture Research 2011. Available online: http://www.oikoskopio.gr/pyroskopio/pdfs/pyrkagiesellada.pdf (accessed on 5 February 2022).

24. Cleveland, W.S. Robust locally weighted regression and smoothing scatterplots. J. Am. Stat. Assoc. 1979, 74, 829-836. [CrossRef]

25. Cleveland, W.S.; McGill, R. The Many Faces of a Scatterplot. J. Am. Stat. Assoc. 1984, 79, 807-822. [CrossRef]

26. Koutsoyiannis, D. Broken Line Smoothing: A Simple Method for Interpolating and Smoothing Data Series. Excel File with VBA Ccode and Calculations. Available online: http://www.itia.ntua.gr/en/getfile/19/3/documents/BLSmooth1.xls (accessed on 5 February 2022).

27. Malamos, N.; Koutsoyiannis, D. Broken line smoothing for data series interpolation by incorporating an explanatory variable with denser observations: Application to soil-water and rainfall data. Hydrol. Sci. J. 2015, 60, 468-481. [CrossRef]

28. Nunes, A.N. Regional variability and driving forces behind forest fires in Portugal an overview of the last three decades (1980-2009). Appl. Geogr. 2012, 34, 576-586. [CrossRef]

29. Abbate, A.; Longoni, L.; Ivanov, V.I.; Papini, M. Wildfire Impacts on Slope Stability Triggering in Mountain Areas. Geosciences 2019, 9, 417. [CrossRef]

30. Yue, C.; Luo, C.; Shu, L.; Shen, Z. A review on wildfire studies in the context of global change. Acta Ecol. Sin. 2020, 40, 385-401. [CrossRef]

31. San-Miguel-Ayanz, J.; Moreno, J.M.; Camia, A. Analysis of large fires in European Mediterranean landscapes: Lessons learned and perspectives. For. Ecol. Manag. 2013, 294, 11-22. [CrossRef]

32. Goodman, J.; Robinsonhttps, O. Forest Fires: Are They Worse than in Previous Years? BBC Reality Check. Available online: www.bbc.com/news/world\$-\$49515462 (accessed on 5 February 2022).

33. DellaSala, D.A.; Hanson, C.T. Large Infrequent Fires Are Essential to Forest Dynamics and Biodiversity in Dry Forests of Western North America. In Reference Module in Earth Systems and Environmental Sciences; Elsevier: Amsterdam, The Netherlands, 2015.

34. Keeley, J.E. Fire: Encyclopedia of Ecology; Jørgensen, S.E., Fath, B.D., Eds.; Academic Press: Cambridge, MA, USA, 2008; pp. 1557-1564.

35. Coen, J. Wildfire Weather, Encyclopedia of Atmospheric Sciences; Holton, J.R., Ed.; Academic Press: Cambridge, MA, USA, 2003; pp. 2586-2596.

36. Rodrigues, A.; Ribeiro, C.; Reis, J.; Sousa, M.; Raposo, J. Wildfires in Northern Portugal: An operational case study in Tabuaço. Proc. Inst. Civ. Eng. Forensic Eng. 2021, 173, 81-94. [CrossRef] 
37. Sharples, J.J.; McRae, R.H.D.; Wilkes, S.R. Wind-terrain effects on the propagation of wildfires in rugged terrain: Fire channelling. Int. J. Wildland Fire 2012, 21, 282-296. [CrossRef]

38. Barbero, R.; Curt, T.; Ganteaume, A.; Maillé, E.; Jappiot, M.; Bellet, A. Simulating the effects of weather and climate on large wildfires in France. Nat. Hazards Earth Syst. Sci. 2019, 19, 441-454. [CrossRef]

39. Potter, B.E. Atmospheric Properties Associated With Large Wildfires. Int. J. Wildland Fire 1996, 6, 71-76. [CrossRef]

40. Fernandes, P.M.; Pacheco, A.P.; Almeida, R.; Claro, J. The role of fire-suppression force in limiting the spread of extremely large forest fires in Portugal. Eur. J. For. Res. 2016, 135, 253-262. [CrossRef]

41. Ciullo, V.; Rossi, L.; Pieri, A. Experimental Fire Measurement with UAV Multimodal Stereovision. Remote Sens. 2020, $12,3546$. [CrossRef]

42. Gašparović, G.; Klarin, B.; Grebo, A.; Mladenović, S. New Concept of Firefighting Aerial Support with Autonomous Unmanned Aerial Systems (AUAS); New Trends in Aviation Development (NTAD): Smokovec, Slovakia, 2020; pp. 78-83.

43. Wildfire Risk Management in the District of Vila Real (Portugal) Proceedings of the Institution of Civil Engineers-Forensic Engineering. Available online: https:/ / www.icevirtuallibrary.com/doi/full/10.1680/jfoen.21.00010 (accessed on 5 February 2022).

44. Meira Castro, A.C.; Nunes, A.; Sousa, A.; Lourenço, L. Mapping the Causes of Forest Fires in Portugal by Clustering Analysis. Geosciences 2020, 10, 53. [CrossRef]

45. Fire in Northern Attica: The Fire Crossed the National Road. Available online: https://www.kathimerini.gr/society/561458653/ fotia-sti-voreia-attiki-dieschise-tin-ethniki-odo-i-pyrkagia/ (accessed on 5 February 2022).

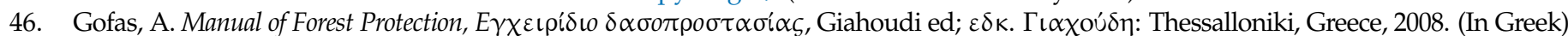

47. Reducing Wildfire Risk in the Wildland-Urban Interface: Policy, Trends, and Solutions, 55. Idaho Law Review. Available online: https:/ / digitalcommons.law.uidaho.edu/idaho-law-review/vol55/iss1/1 (accessed on 2 February 2022).

48. National Geographic. Controlled Burning. Available online: https://www.nationalgeographic.org/encyclopedia/controlledburning/ (accessed on 5 February 2022).

49. Dimitriadis, P.; Iliopoulou, T.; Sargentis, G.-F.; Koutsoyiannis, D. Spatial Hurst-Kolmogorov Clustering. Encyclopedia 2021, 1, 77. [CrossRef]

50. Sargentis, G.-F.; Iliopoulou, T.; Sigourou, S.; Dimitriadis, P.; Koutsoyiannis, D. Evolution of Clustering Quantified by a Stochastic Method-Case Studies on Natural and Human Social Structures. Sustainability 2020, 12, 7972. [CrossRef]

51. Sargentis, G.-F.; Ioannidis, R.; Karakatsanis, G.; Sigourou, S.; Lagaros, N.D.; Koutsoyiannis, D. The Development of the Athens Water Supply System and Inferences for Optimizing the Scale of Water Infrastructures. Sustainability 2019, 11, 2657. [CrossRef]

52. Bairaktaris, I. The Scale Issues in Hydroelectric Energy: Many Small Projects or a Large One? Master's Thesis, National Technical University of Athens, Athens, Greece, November 2020.

53. Of Mice and Elephants: A Matter of Scale. Science. Available online: http://courses.missouristate.edu/chrisbarnhart/bio121 /lab / respiration/of_mice_and_elephants.htm (accessed on 2 February 2022).

54. Asian Elephant Nutrition, Energy Expenditure. Available online: https://asianelephantnutrition.wordpress.com/2015/02/25 /big-body-lots-of-energy-maintenance/ (accessed on 5 February 2022).

55. Bermingham, E.; Thomas, D.; Morris, P.; Hawthorne, A. Energy requirements of adult cats. Br. J. Nutr. 2010, 103, 1083-1093. [CrossRef] [PubMed]

56. National Research Council (US). Subcommittee on Laboratory Animal Nutrition. Nutrient Requirements of Laboratory Animals, 4th ed.; National Academies Press: Washington, DC, USA, 1995.

57. Koutsoyiannis, D. Scale of water resources development and sustainability: Small is beautiful, large is great. Hydrol. Sci. J. 2011, 56, 553-575. [CrossRef]

58. How to survive mass extinction. The Guardian. 20 September 2022. Available online: https://www.theguardian.com/science/ lost-worlds/2012/sep/20/dinosaurs-fossils (accessed on 2 February 2022).

59. Portugal Wildfire Management in a New Era. Assessing Fire Risks, Resources and Reforms. Available online: https://www.isa ulisboa.pt/files/cef/pub/articles/2018-04/2018_Portugal_Wildfire_Management_in_a_New_Era_Engish.pdf (accessed on 17 January 2022).

60. Arianoutsou, M. Resilience of Mediterranean vegetation to fire: Issues under the global change scenarios. In Proceedings of the MEDECOS XI 2007 Conference, Kings Park and Botanic Garden, Perth, Australia, 2-5 September 2007; pp. 5-7.

61. Mermoz, M.; Kitzberger, T.; Veblen, T.T. Landscape influences on occurrence and spread of wildfires in patagonian forests and shrublands. Ecology 2005, 86, 2705-2715. [CrossRef]

62. Syphard, A.D.; Brennan, T.J.; Keeley, J.E. The role of defensible space for residential structure protection during wildfires. Int. J. Wildland Fire 2014, 23, 1165-1175. [CrossRef]

63. Bajocco, S.; Ricotta, C. Evidence of selective burning in Sardinia (Italy): Which land-cover classes do wildfires prefer? Landsc. Ecol. 2008, 23, 241-248. [CrossRef]

64. Odum, E.P. The Strategy of Ecosystem Development Science. In The Ecological Design and Planning Reader; Ndubisi, F.O., Ed.; Island Press: London, UK, 2014; Available online: https:/ link.springer.com/content/pdf/10.5822/978-1-61091-491-8.pdf (accessed on 17 January 2022).

65. Mateus, P.; Fernandes, P.M. Forest Fires in Portugal: Dynamics, Causes and Policies. In Forest Context and Policies in Portugal. World Forests; Reboredo, F., Ed.; Springer: Cham, Switzerland, 2014. 
66. Sargentis, G.-F.; Siamparina, P.; Sakki, G.-K.; Efstratiadis, A.; Chiotinis, M.; Koutsoyiannis, D. Agricultural Land or Photovoltaic Parks? The Water-Energy-Food Nexus and Land Development Perspectives in the Thessaly Plain, Greece. Sustainability 2021, 13, 8935. [CrossRef]

67. Sargentis, G.-F.; Dimitriadis, P.; Ioannidis, R.; Iliopoulou, T.; Koutsoyiannis, D. Stochastic Evaluation of Landscapes Transformed by Renewable Energy Installations and Civil Works. Energies 2019, 12, 2817. [CrossRef]

68. Ioannidis, R.; Koutsoyiannis, D.; Sargentis, G.-F. Landscape design in infrastructure projects-is it an extravagance? A cost-benefit investigation of practices in dams. Landsc. Res. 2022; under publication.

69. Ioannidis, R.; Koutsoyiannis, D. A Review of Land Use, Visibility and Public Perception of Renewable Energy in the Context of Landscape Impact. Appl. Energy 2020, 276, 115367. [CrossRef]

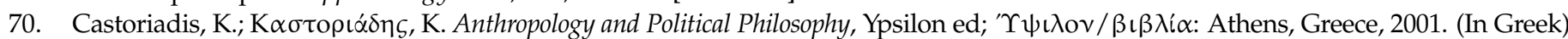

71. Filotis. Data Base for Hellenic Nature. Available online: https:/ / filotis.itia.ntua.gr/biotopes/ (accessed on 5 February 2022).

72. Evaluation, Review and Specific Aspects of the Regional Spatial Planning and Sustainable Development of the Region of Central

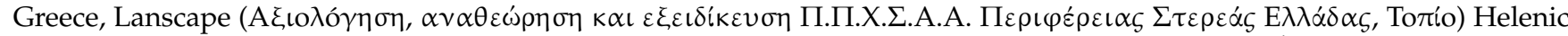

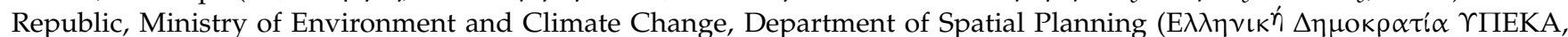
$\Delta / v \sigma \eta X \omega \rho o \tau \alpha \xi(\alpha \zeta)$. February 2014. Available online: https://dimoslevadeon.gr/wp-content/uploads/2015/07/2-topio.pdf (accessed on 5 February 2022).

73. Google. Google Earth Pro, Version 7.3.3.7786; Map Publisher: Washington, DC, USA, 2021.

74. ECI-Engineering Consultants INC. Kremasta Project Report; Technical Report prepared for Public Power Corporation $(\Delta \mathrm{EH})$; ECI-Engineering Consultants INC: Boise, ID, USA, 1974.

75. Frontpages of the Bigest Newspaper of the World. Available online: https://www.marieclaire.gr/art-lifestyle/body-mind/ newsroom/h-kravgi-tis-81chronis-giagias-stin-evvia-protoselido-stis-megaliteres-efimerides-tou-kosmou/ (accessed on 15 October 2021).

76. Kontoes, C.; Keramitsoglou, I.; Papoutsis, I.; Sifakis, N.I.; Xofis, P. National Scale Operational Mapping of Burnt Areas as a Tool for the Better Understanding of Contemporary Wildfire Patterns and Regimes. Sensors 2013, 13, 11146-11166. [CrossRef]

77. Firehub. Available online: http:/ / ocean.space.noa.gr/diachronic_bsm/ (accessed on 15 October 2021).

78. EUMETSAT, NASA/NOAA/GSFC/EOSDIS, Suomi-NPPVIRS, NWS/GFS, FIRMS. Available online: https://zoom.earth/ (accessed on 15 October 2021).

79. NASA WORLDVIEW. Available online: https://worldview.earthdata.nasa.gov/ (accessed on 15 October 2021).

80. 112 Emergency Communications Service: 112 Greece. Available online: https:/ / twitter.com/112Greece (accessed on 15 October 2021).

81. Meteorological Data. Available online: https://www.meteoblue.com/ (accessed on 15 October 2021).

82. Lakes Software, WRPLOT VIEW Software VERSION 8.0.2. Available online: https://www.weblakes.com/software/freeware/ wrplot-view/ (accessed on 2 February 2022).

83. February 2021 Greek Cold Wave. Available online: https://en.wikipedia.org/wiki/February_2021_Greek_cold_wave (accessed on 2 February 2021).

84. Aspects of the Cold Wave Medea in North Euboea. Available online: https:/ / www.egnomi.gr/article/124067/ritinokalliergites_ boreiokentrikis_eyboias_toys_afanise_mideia.html (accessed on 2 February 2021).

85. Alteregomedia. Available online: http:/ / premiumarchives.alteregomedia.org/ (accessed on 15 October 2021). (In Greek).

86. Georgantzis, V. Personal communication, 2021.

87. The Invisible Victims of the Fires-9000 Beehives and Tons of Honey Were Lost. Available online: https://www.meteo24news.gr/2021 /08/Ta-afani-thimata-ton-pirkagion-xathikan-enia-xiliades-melisosmini-ke-toni-meliou.html (accessed on 15 October 2021).

88. Euboea: 9000 Beehives and 65\% of the Pine Honey Were Lost! Available online: https://www.naftemporiki.gr/story/1765769/ (accessed on 15 October 2021).

89. We lose up to 10,000 Tons of Pine Honey a Year Due to Fires. Available online: https://www.iefimerida.gr/ellada/hanoyme-10 000-tonoys-peykomelo-logo-pyrkagion (accessed on 15 October 2021).

90. Hellenic Statistical Authority. Livestock Production in Euboea. Census 2019. Available online: https://www.statistics.gr/en/ statistics / - publication/DKT30/2019-M06 (accessed on 2 February 2022).

91. Low 4824/2021. Available online: https:/ / dasarxeio.com/wp-content/uploads/2021/09/n_4824_2021.pdf (accessed on 27 June 2021).

92. Mamassis, N.; Efstratiadis, A.; Dimitriadis, P.; Iliopoulou, T.; Ioannidis, R.; Koutsoyiannis, D. Water and Energy. In Handbook of Water Resources Management: Discourses, Concepts and Examples; Bogardi, J.J., Gupta, J., Nandalal, K.D.W., Salamé, L., van Nooijen, R.R.P., Kumar, N., Tingsanchali, T., Bhaduri, A., Kolechkina, A.G., Eds.; Springer International Publishing: Cham, Switzerland, 2021; pp. 619-657. ISBN 978-3-030-60147-8.

93. Greek Constitution. Available online: https://www.hellenicparliament.gr/Vouli-ton-Ellinon/To-Politevma/Syntagma/ (accessed on 15 October 2021).

94. Forest Management. Legislative Decree 86/1969. Available online: http://www.fdparnonas.gr/files/ND86_69.pdf (accessed on 15 October 2021).

95. Law 4264/2014. Available online: https://www.kodiko.gr/nomologia/download_fek?f=fek/2014/a/fek_a_118_2014.pdf\&t=e5 18855486f0aa6e8d244d08a282e55f (accessed on 15 October 2021). 
96. Castro, M.; Fernández-Núñez, E. Seasonal Grazing of Goats and Sheep on Mediterranean Mountainrangelands of Northeast Portugal. Livestock Research for Rural Development. Available online: http:/ / www.lrrd.org/lrrd28/5/cast28091.html (accessed on 15 October 2021).

97. den Herder, M.; Helle, S.; Niemelä, P.; Henttonen, H.; Helle, T. Large herbivore grazing limits small mammal densities in Finnish Lapland. Ann. Zool. Fenn. 2016, 53, 154-164. [CrossRef]

98. Der Herden, M.; Amaral Paulo, J. Sheep as Forest Managers: Management of Young Forest Stands by Grazing Sheep, AFINET (Agroforestry Innovation Networks), Horizon 2020 N. 727872. Available online: https:/ / euraf.isa.utl.pt/files/pub/newsletter4 _sheep_as_forest_managers_management_of_young_forest_stands_by_grazing_sheep.pdf (accessed on 5 November 2021).

99. Managing the Complexities of Land \& Livestock. Available online: https:/ / savory.global/holistic-management/ (accessed on 15 October 2021).

100. Chandler, C.; Cheney, P.; Thomas, P.; Trabaud, L.; Williams, D. Fire in forestry. In Forest Fire Behavior and Effects. Volume 2. Forest Fire Management and Organization; John Wiley \& Sons Inc.: New York, NY, USA, 1983; Volume 1.

101. Mousourakis, A.; Arakadaki, M.; Kotsopoulos, S.; Sinamidis, I.; Mikrou, T.; Frangedaki, E.; Lagaros, N.D. Earthen Architecture in Greece: Traditional Techniques and Revaluation. Heritage 2020, 3, 68. [CrossRef]

102. Apostolou, M. The Rehabilitation of the Refugees by Asia Minor Catastrophe: The Role of the Greek State and Foreigners Forces. Bachelor's Thesis, TEI Kalamatas, Oktober 2007. Available online: http://nestor.teipel.gr/xmlui/bitstream/handle/123456789/ 12655/SDO_DMYP_00630_Medium.pdf?sequence=1 (accessed on 15 October 2021).

103. Marx, K. Capital. A Critique of Political Economy. In Das Kapital: Kritik der politischen Oekonomie; Verlag von Otto Meissner: Hamburg, Germany, 1867.

104. Sitton, J.F. Critique of the Gotha Programme. In Marx Today; Sitton, J.F., Ed.; Palgrave Macmillan: New York, NY, USA, 2010. [CrossRef]

105. Keynes, J.M. The General Theory of Employment, Interest and Money; Palgrave Macmillan: London, UK, 1936.

106. Friedman, M.A. Program for Monetary Stability; Fordham University Press: New York, NY, USA, 1960.

107. Hayek, F.A. The Constitution of Liberty; University of Chicago Press: Chicago, IL, USA, 1960.

108. Jackson, T. Prosperity without Growth? The Transition to a Susianable Economy, UK Govement, Sustainable Development Commission. March 2009. Available online: http://www.sd-commission.org.uk/data/files/publications/prosperity_without_ growth_report.pdf (accessed on 9 August 2021).

109. Latouche, S. The Path to Degrowth for a Sustainable Society. In Factor X. Eco-Efficiency in Industry and Science; Lehmann, H., Ed.; Springer: Cham, Switzerland, 2018; Volume 32, pp. 277-284.

110. Latouche, S. Degrowth Economics. Le Monde Diplomatique. 2004. Available online: https://www.jussemper.org/Resources/ Economic\%20Data/Resources/Degrowth\%20economics,\%20by\%20Serge\%20Latouche.pdf (accessed on 5 February 2022).

111. Galbraith, J.K. Economics in Perspective: A Critical History; Houghton Mifflin: Boston, MA, USA, 1987.

112. Malthus, T.R. An Essay on the Principle of Population; Johnson, J., Ed.; Pickering \& Chatto Publishers: London, UK, 1798.

113. El-Sayegh, S.R. A Critical Review of 3D Printing in Construction: Benefits, Challenges, and Risks. Archives of Civil and Mechanical Engineering; Springer: Cham, Switzerland, 2020; Volume 20, pp. 1-25.

114. Media Invited to Final Competition of NASA's 3D-Printed Habitat Challenge. Available online: https://www.nasa.gov/ directorates/spacetech/centennial_challenges/M19-012.html (accessed on 17 January 2022).

115. Perrot, A.R. 3D Printing of Earth-Based Materials: Processing Aspects. Construction and Building Materials; Elsevier: Amsterdam, The Netherlands, 2018; Volume 172, pp. 670-676.

116. Fire Euboea-Deputy Mayor of Mantoudi: 1000 Houses Were Burnt. Available online: https://www.ethnos.gr/greece/article/16 9611/fotiaeyboiaantidhmarxosmantoydioyeginanstaxth1000spitia (accessed on 15 October 2021).

117. Helenic Ministry of Environment and Energy: Simplification of the Procedure for Pruning and Removal of Trees in Private Areas. Available online: https:/ /ypen.gov.gr/aplopoieitai-i-diadikasia-gia-kladefseis-kai-apomakrynseis-dentron-se-idiotikes-ektaseisektos-orion-oikismou/ (accessed on 15 October 2021).

118. Ascoli, D.; Moris, J.V.; Marchetti, M.; Sallustio, L. Land Use Change towards Forests and Wooded Land Correlates with Large and Frequent Wildfires in Italy. Ann. Silvic. Res. Crea J. 2021, 46. [CrossRef]

119. Population in Greece. Available online: https://www.worldometers.info/world-population/greece-population/ (accessed on 5 November 2021).

120. Koukoumakas, K. The People Who Lived from the Forest. 28 August 2021. Available online: https://www.news247.gr/sundayedition/eyvoia-oi-anthropoi-poy-zoysan-apo-to-dasos.9335640.html (accessed on 3 February 2021). 